\title{
Pathology and Nematology
}

\author{
Bob Trigiano \\ Section Editor and Moderator
}




\title{
Downy Mildew of Coleus: A First Report in Tennessee
}

\author{
A.S. Windham ${ }^{1}$, M.T. Windham ${ }^{2}$, L. Self ${ }^{3}$ \\ ${ }^{1}$ University of Tennessee, Nashville, TN 37211 \\ ${ }^{2}$ University of Tennessee, Knoxville, TN 37996-4560 \\ ${ }^{3}$ Tennessee Department of Agriculture, Nashville, TN 37220
}

Index words: coleus, downy mildew, Peronospora sp.

Significance to Industry: In 2006, downy mildew caused by a Peronospora $s p$. was observed on vegetatively propagated coleus, Solenostemon scutellarioides, at a retail garden center, a wholesale greenhouse and a public garden. This is a first report of this disease on coleus in Tennessee.

Nature of Work: Vegetatively propagated coleus has become a very popular annual bedding plant in residential and commercial gardens. Few diseases have been reported on coleus. In 2005, Daughtrey et al. (1) reported that downy mildew had been identified on coleus in Louisiana and New York. By the spring of 2006, downy mildew had been reported in 13 states (Margery Daughtrey, personal communication). The causal agent was a Peronospora species that had morphological characteristics consistent with Peronospora lamii, but was later found to be taxonomically distinguishable from $P$. lamii when tested by molecular methods (1).

Weather patterns in middle Tennessee in April and early May 2006 were wetter and cooler than normal. In May 2006, coleus was observed in a retail garden center in Nashville, TN with necrotic lesions and chlorotic leaves (Figure 1). Upon examination at 40X with a dissecting scope, masses of hyaline conidiophores were visible on the underside of leaves, beneath foliar chlorotic and necrotic lesions. Conidia were removed from the leaves, mounted in water on a microscope slide with a glass cover slip and examined at $100-400 \mathrm{X}$ (Figure 2). Conidiophores were dichotomously branched placing the fungus in the genus Peronospora.

In June 2006, a Nashville, TN area wholesale greenhouse brought a flat of coleus to the UT Plant and Pest Diagnostic Center due to severe stunting. Peronospora was sporulating profusely on the foliage of the infected plants. Severely infected plants were partially defoliated. It appeared that the plants were systemically infected with downy mildew.

In October 2006, coleus from the UT Trial Gardens was submitted for examination due to poor growth and necrotic leaf lesions. Sparse sporulation of Peronospora was visible on the underside of leaves with necrotic lesions. 
Results and Discussion: Coleus from three locations in Tennessee were diagnosed as being infected with downy mildew caused by a Peronospora $s p$. in 2006. Although not widespread in occurrence, it was causing serious damage to infected plants when observed. As downy mildew symptoms are variable and not readily recognized by growers, it is quite probable that other coleus plantings affected by downy mildew were not diagnosed properly. Although, coleus appears to be the primary host for this particular Peronospora sp., anise hyssop (Agastache hybrids) was recently reported to be susceptible to the downy mildew pathogen found on coleus (2).

Growers need to be aware of the symptomatology of downy mildew so that infected plants may be identified and discarded. Preventive measures in greenhouses include keeping foliage dry by using drip irrigation, maintaining the relative humidity level below $85 \%$ by venting, and by using protectant fungicides such as dimethomorph, fenamidone or azoxystrobin.

\section{Literature Cited:}

1. Daughtrey, M. L., G. E. Holcomb, B. Eshenaur and M. E. Palm. 2006. First report of Downy Mildew on Greenhouse and Landscape Coleus Caused by a Peronospora sp. in Louisiana and New York. Plant Dis. 90:1111.

2. Daughtrey, M. L. and M. Tobiasz. 2006. An Additional Host and Management Tools for Downy Mildew of Coleus. Abstracts of the 2006 Northeastern Meeting of the American Phytopathological Society. http://www.apsnet.org/meetings/div/ne06abs.asp

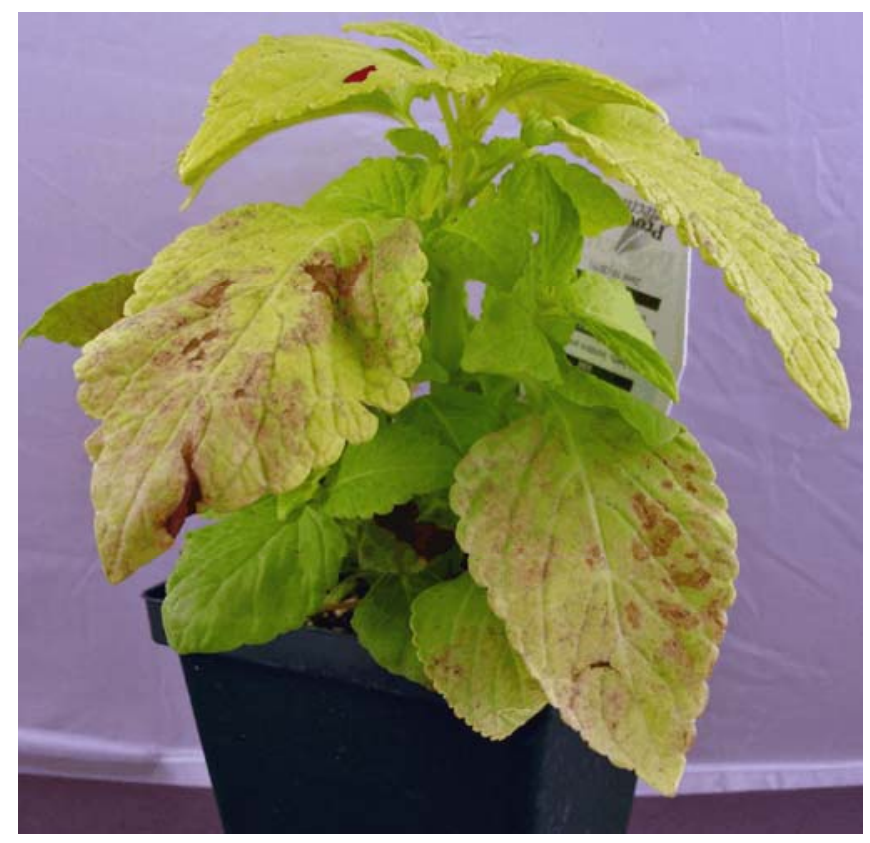

Figure 1. Coleus with necrotic lesions and discolored foliage infected with downy mildew. 
SNA Research Conference Vol. 522007

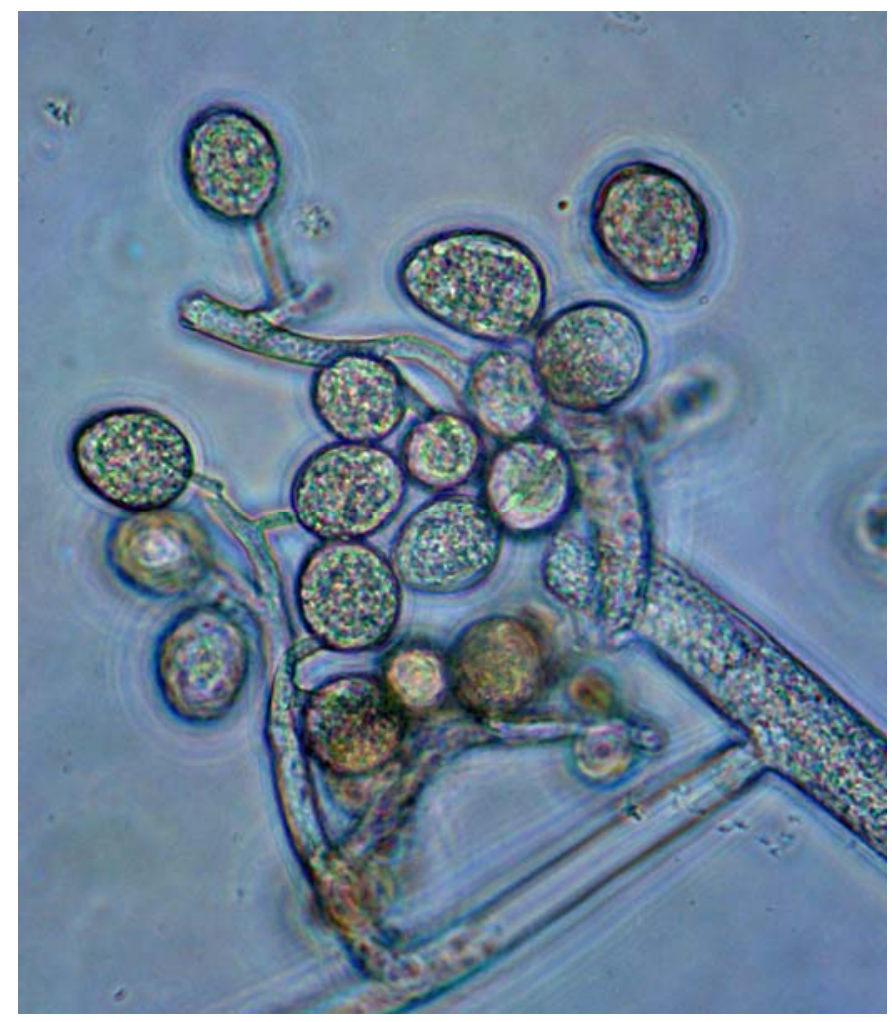

Figure 2. Conidia and a conidiophore of a Peronospora sp. observed on Coleus. 


\title{
Biofungicide and Conventional Control of Rhizoctonia solani in a Container Production System
}

\author{
Sarah Stolz, Julie Beale, Leah Dougherty, \\ Sara Long, Amy Fulcher, and Robert Geneve \\ University of Kentucky, Departments of Horticulture and Plant Pathology \\ Lexington, KY 40546 \\ afulcher@uky.edu
}

Index Words: flowering dogwood, Trichoderma, Rhizoctonia root rot, nursery

Significance to the Industry: Flowering dogwood is a nursery crop with potential for the container production industry. Controlling root rot is an essential component to successful container production of dogwood. Identifying sustainable methods of controlling root rot will greatly enhance survival and growth of container production of dogwood while promoting environmental stewardship.

Nature of Work: Dogwood, in particular our native flowering dogwood, Cornus florida, is a high value crop, with gross returns of $\$ 60,000$ per acre possible (4). While dogwoods have traditionally been field produced and marketed as balled and burlapped plants, recent consumer trends show an increased demand for container-produced plants (2). However, dogwoods have been difficult to grow in containers and commonly have poor vigor and high mortality (5).

Preliminary experiments and laboratory diagnostics showed that an impediment to dogwood container production is root rot caused by the fungus Rhizoctonia solani. Rhizoctonia solani is non-host specific, having many anastomosis groups and races within these anastomosis groups. This diversity allows the species to infect a wide host range including vegetables, flowers, field crops, turf grasses, and perennial ornamental shrubs and trees (1). R. solani survives saprophytically in the soil and is capable of surviving for long periods of time (1). Rhizoctonia is spread by rain, irrigation, implements, and anything that carries field soil or substrate. Infected roots appear fleshy brown to iridescent color with few to no root hairs, causing inefficient water and nutrient uptake (3). Rapidly growing plants appear to resist infection even when environmental conditions are conducive for fungal growth, however slowly growing young plants produced under stressful environments are more prone to infection (1). Determining an effective control for Rhizoctonia root rot disease would increase the percentage of plants that live and thrive and, thus, help to create a viable and economically profitable production system.

Additionally, a sustainable approach to controlling fungal pathogens is beneficial to consumers, retailers, and nursery producers. Growers using biofungicides 
preserve water quality, reduce employee exposure to harmful chemicals, and eliminate REls, the period during which workers may not enter a pesticidetreated area unless wearing prescribed personal protective equipment. Retailers and wholesalers can market plants as sustainably-produced, and biofungicides, which are approved for certified organic production, offer additional production and marketing advantages. Adoption of biocontrols helps to ensure that growers are not dependent on conventional pesticides, which are increasingly less available. A sustainable control of $R$. solani in dogwood container production would be economically beneficial to several segments of the green industry and would contribute to sound environmental stewardship. Therefore our objective was to evaluate Trichoderma-based fungicides for control of $R$. infections of $C$. florida in container production.

Upon receipt, 18-24" bareroot liners of C. florida 'Cherokee Princess' were examined for the presence of existing $R$. solani infections and graded based on the level of infection. The bark substrate was tested for presence of $R$. solani via an ELIZA test (ADGEN Agrifood Diagnostics). Rhizoctonia was detected in the substrate, and while not confirmed as the species $R$. solani, a steamed substrate treatment was included. Bareroot liners were potted into \#3 trade-gallon containers (Nursery Supplies, Inc., McMinnville, OR) with either steam-treated or untreated Barky Beaver Professional Grow mix (Barky Beaver Mulch and Soil Mix, Inc., Moss, TN) on February 23, 2007. The treatments, which were applied at the time of planting, consisted of the following:

- Dipping liners for 5 seconds in a PlantShield® HC slurry, 0.5 pounds per 5 gallons water, (BioWorks, Inc., Fairport, NY)

- Topdressing with RootShield® Granules (BioWorks, Inc., Fairport, NY), 4.5 grams per plant, followed by irrigation;

- Drenching with PlantShield HC, (BioWorks, Inc., Fairport, NY), 2.8 grams per 5 gallons water, 1 quart per plant;

- Drenching with $3336^{\mathrm{TM}}$ (Cleary's Chemical Corp., Dayton, NJ), $5 \mathrm{ml}$ per gallon water, 2 quarts per plant;

- Potting into steamed substrate followed by irrigation;

- Drenching with a water control, 1 quart per plant.

Containers were placed in a randomized complete block design with 10 replications, $n=60$. The experiment was blocked on health of root system, as determined by the extent of the preexisting Rhizoctonia infection. Plants were grown in a controlled environment greenhouse at the University of Kentucky, Lexington, $\mathrm{KY}$.

Two weeks after transplanting, one-half of the plants were sampled, with alternating sampling every week, such that over a two week period, all of the plants were sampled. This sampling schedule continued through the end of April 2007. Roots were sampled by collecting three sections of root from two sides of 
each container and preparing one slide per root section (six slides total per plant). Slides were examined for presence of $R$. solani hyphae. Stems and leaves were ranked for healthy appearance and growth on a 5 point scale eight weeks after treatment.

Results and Discussion: It should be noted that the biofungicides included in this trial are marketed based on their ability to prevent infections, which is accomplished by colonizing the root surface prior to infection. These products are not marketed as curative treatments.

No treatment eliminated the spread of Rhizoctonia, though all Trichoderma treatments resulted in a decrease in Rhizoctonia over the course of the experiment (Table 1). The steamed treatment, which was added to the study to determine the importance of the substrate as an additional source of inoculum, showed a decline similar to the Trichoderma treatments. Plants treated with the conventional fungicide treatment exhibited a decrease in Rhizoctonia presence as did the water control (Table 1). The authors hypothesize that over time new root growth resulted in decreased sampling of infected roots causing a bias in sampling and data analysis. Data (not shown) from the visual rating of above ground growth and inspection of roots during sampling support that the conventional fungicide treatment gives rise to healthy-looking plants with abundant new root growth making this the best treatment. Current work includes a conventional fungicide drench prior to the initiation of the experiment in order to eliminate preexisting Rhizoctonia infections. In addition, modified root sampling protocols have been developed and an ELIZA will be conducted on root samples.

The authors acknowledge BioWorks, Inc., Fairport, NY for its donation of RootShield $₫$ and PlantShield $\circledast$.

\section{Literature Cited:}

1. Agrios, G. N. 2005. Plant Pathology. 3rd ed. Academic Press, Inc. San Diego, CA

2. Basham, A., M. Ernst, and T. Woods. 2004. 2004 Nursery Products Buyer Survey. UK Nursery and Landscape Program Research Report. PR-409:1920.

3. Parmeter, J. R. 1970. Phizoctonia Solani, Biology and Pathology. University of California Press. Berkeley, CA

4. Witte, W. 1995. Dogwood Culture in Nursery and Landscape. Tennessee Agri Science. P. 47-51.

5. Witte, W. and K. Tilt. 1991. Experiments on container tree growing and establishment. Proc. Joint Intl. Symposium on Efficiencies of Producing and Marketing Landscape Plants. Boskoop, The Netherlands. P. 117-134. 
Table 1. Effect of treatments on incidence of Rhizoctonia; (Data represent the 5 blocks containing the healthiest initial root systems.)

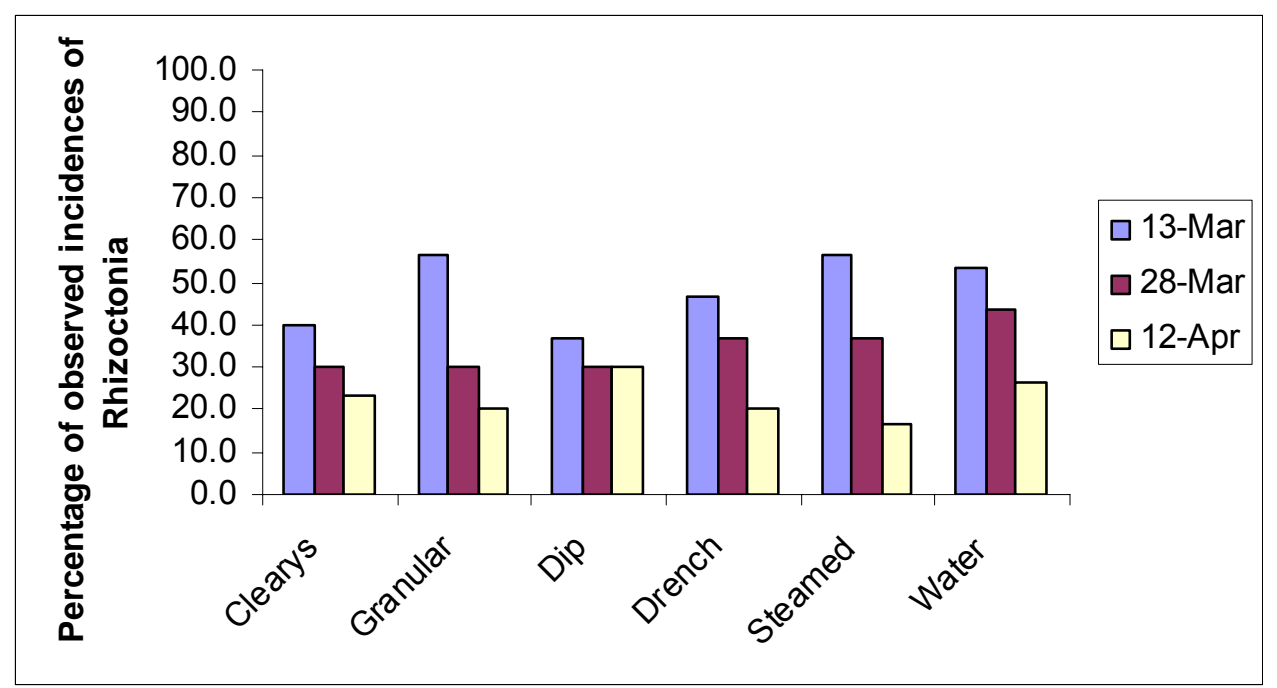




\title{
Impact of Monarda Herbage on Growth of Rooted Cuttings
}

\author{
Kimberly D. Gwinn, Bonnie H. Ownley, and Sharon E. Greene \\ The University of Tennessee, Knoxville \\ Department of Entomology and Plant Pathology, Knoxville, TN 37966-4560
}

kgwinn@utk.edu

Index Words: Bioactive herbage, fuchsia, licorice plant, monarda, poinsettia, root and stem rot, rooted cuttings.

Significance to the Industry: Root and stem rots are common problems in production of plants from cuttings. Natural bioactive compounds that have fungicidal properties, present in Monarda didyma, M. fistulosa, and M. clinopodia can be used to control seedling diseases caused by Pythium myriotylum and Rhizoctonia solani, but these compounds may also reduce plant quality and viability. Amendment of planting mix with monarda herbage (dried and ground leaves and stems of Monarda spp.) is an effective means of delivering the bioactive compounds, and may be an effective control for root and stem rots in plant production from cuttings. However, the impact on plant growth and development must be determined.

Nature of the Work: The goal of our research is to identify monarda herbage that can be incorporated into planting mix and provide protection against plant pathogens without reducing plant growth or quality. In order to utilize this technology fully, it is critical to determine impact of monarda herbage on plants and to evaluate its use in commercial greenhouses. The objective of this study was to evaluate the effect of monarda herbage on the quality and growth of rooted cuttings of several plant species, including licorice plant (Helichrysum petiolare Hilliard \& Burtt), fuchsia (Fuchsia L.), impatiens (Impatiens walleriana Hook. f.), New Guinea impatiens (Impatiens hawkeri Hook f.), and poinsettia (Euphorbia pulcherrima Willd. ex Klotzsch) in commercial greenhouses.

Monarda herbage. Varieties of Monarda didyma and M. fistulosa were grown in The Monarda Evaluation Garden, Knoxville, TN. Leaves and flowers were collected, air-dried, ground, sieved (5-mm mesh), and stored in sealed glass jars. For most experiments, 'super mixes' were prepared from herbage collected in 2002 and 2003. For experiments with poinsettia, herbage samples from 2003 and 2004 were mixed.

Licorice Plant and Fuchsia. 'Super mixes' from three varieties of herbage of Monarda spp. ('Sioux', 'Marshall's Delight' or 'Puerto Purification') were added to Fafard potting mix (Conrad Fafard, Inc., Agawam, MA) at 0 and 10\% v/v. Standard procedures for sticking cuttings were followed by employees at Williams Farms, Rutledge, TN. After 4 weeks, plants were harvested and root dry weights (RDW) 
were determined. In a second experiment, 'Puerto Purification' super mix was added to BM-1 planting mix (Berger Peat Moss Inc., Saint Modeste, Quebec, Canada) at 0,5 and $10 \%$, and 'Trinity Purple' was added to BM-1 at rates of 0,1 , and $2 \%$.

Impatiens and New Guinea Impatiens. Monarda herbage was mixed with BM-1 as described for licorice plant except that three monarda 'super mixes' were added ('Fishes', 'Mohawk' and M. clinopodia) at 0, 5, and 10\%. Pope's Plant Farm, Greenback, TN purchased unrooted impatiens cuttings from Ball Horticultural, West Chicago, IL and unrooted New Guinea impatiens from Oro Farms, Baldwinsville, NY. Cuttings were rooted using standard protocols. The resulting plugs were planted into BM-1 or BM-1 + monarda herbage, and standard production procedures were followed. Plants were rated every 2 weeks on a 1 to 3 scale based on size and quality. After 6 weeks, plants were harvested at the soil line and fresh weights were determined. Roots of selected controls were examined for disease symptoms.

Poinsettia. Monarda herbage was mixed with BM-6, then stored in plastic bags for 1 month before use. Herbage from 'Croftway Pink', 'Mahogany', and 'Trinity Purple' were evaluated at 0 and 10\% (v/v); 'Trinity Purple' herbage also was evaluated at 5\%. Poinsettia callused cuttings (Paul Ecke Ranch, Encinitas, CA) were planted in 6-inch-pots at Stanley's Greenhouses, Knoxville, TN. Plant quality was evaluated every 3 weeks on a 1 to 5 scale, where $1=$ poor and $5=$ excellent. At 12 weeks, plant height and inflorescence diameter were measured and floral development was evaluated on a scale of 1 to 7 (3).

Results and Discussion: Licorice plant and fuchsia. Fuchsia and licorice plant rooted cuttings produced in monarda herbage-amended mix did not look different from control plants without herbage. In Test 1, the RDW of licorice plant was not affected by treatment with monarda herbage from 'Marshall's Delight', but was decreased by $43 \%$ when planting mix was amended with 'Sioux' and by $34 \%$ when mix was amended with 'Puerto Purification'. The RDW of fuchsia was not affected by herbage from 'Sioux' or 'Puerto Purification, but was decreased by $45 \%$ when mix was amended with 'Marshall's Delight'. In Test 2, no treatment was different from the control or other treatments.

Impatiens and New Guinea impatiens. Plant weight and quality ratings of impatiens and New Guinea impatiens rooted in Monarda-amended mix were not different than control plants without herbage. There were no disease symptoms in control plants. All plants in the study were marketable and were flowering by the end of the study.

Poinsettia. At 3 weeks, $79 \%$ of poinsettia cuttings grown in mix amended with 5 or $10 \%$ 'Trinity Purple' were dead (Fig. 1). Of the remaining plants, quality was reduced by $60 \%$. By 9 weeks, only one of the plants treated with 'Trinity Purple' was marketable. At 3 weeks, the quality of cuttings in mix amended with 
'Croftway Pink' or 'Mahogany' were indistinguishable from controls without herbage, however by 6 weeks, the quality of plants grown in mix amended with 'Mahogany' was reduced by $24 \%$. At 9 weeks, plant quality was reduced by $40 \%$ with 'Croftway Pink' herbage, and by $48 \%$ in 'Mahogany' treatments. Plants treated with either 'Croftway Pink' or 'Mahogany' were not marketable.

Monarda herbage can protect seedlings against damping-off disease caused by Pythium and Rhizoctonia. This research was designed to determine if monarda herbages that are known to reduce seedling losses due to Rhizoctonia solani (2) or Pythium myriotylum (1) would negatively impact rooted cutting production. 'Mahogany' was the only monarda herbage used in these experiments that did not reduce losses due to $R$. solani or to $P$. myriotylum (authors, unpublished).

Impact of monarda herbage on plant growth and development differed depending upon the combination of plant and monarda herbage. Licorice plants were sensitive to 'Sioux' and 'Puerto Purification', whereas, fuchsia was sensitive to 'Marshall's Delight'. Seed germination, growth and development of impatiens were inhibited by many monarda herbages, including some used in this study. While there were differences among the treatments in this study, all Impatiens spp. were marketable at the end of the study. A rate of monarda herbage that will not negatively impact rooting and growth in retail poinsettia production was not identified. Poinsettias were very sensitive to the bioactive compounds found in monarda herbage. All herbages lowered quality ratings of poinsettia, and few plants survived in 'Trinity Purple'-amended mix, even at the 5\% rate. Reducing application rates or use of other monarda herbages will be necessary if this technology is to be used by poinsettia growers. The lack of disease symptoms in the control plants of impatiens and New Guinea impatiens indicate a lack of disease pressure. In the absence of disease pressure, there were no negative impacts of monarda herbage on growth and quality of either species of Impatiens. Based on these data, monarda herbage amendments are an acceptable disease management tool for use in impatiens, New Guinea impatiens and licorice plant.

\section{Literature Cited:}

1. Clark, M.M. 2006. Biological Control Methods for Damping-Off of Tomato Seedlings Caused by Pythium myriotylum. M.S. Thesis. The University of Tennessee.

2. Gwinn, K.D., S.E. Greene, and B.H. Ownley. 2007. Monarda Bioactive Herbage Reduces Rhizoctonia Disease Losses in Tomato Transplants (abstract). Phytopathology 97: in press.

3. Williams, K.A., Warnock, D.F. and Catanzaro, C.J. 2007. Regional poinsettia trials. 2004 season. Description of data. http://www.oznet.kstate.edu/poinsettias/2004/DescriptionOfData.htm. Accessed May 18, 2007. 
Fig. 1. Impact of monarda herbage on production of rooted cuttings. (A) Rooted cuttings of Fuchsia grown in control or monarda-amended planting mix. Cuttings were planted in mix containing either no monarda herbage (control) or herbage from one of three varieties: Mon-29 = 'Puerto Purification'; Mon-20 = 'Sioux'; Mon-39 = 'Marshall's Delight'. (B) Poinsettia cuttings 3 weeks after planting into BM-6 with or without monarda herbage. Plant quality and survival were determined every 3 weeks after planting until controls were marketable. Plants with a yellow or blue marker were treated with 5 or $10 \%$ 'Trinity Purple' herbage, respectively. Plants with pink markers were treated with 'Croftway Pink'. Orange markers indicate plant number. At 3 weeks after planting, there were no differences in plants grown in mix amended with 'Croftway Pink' and the controls. However, plant quality was significantly reduced at the end of the experiment and plants were not marketable.

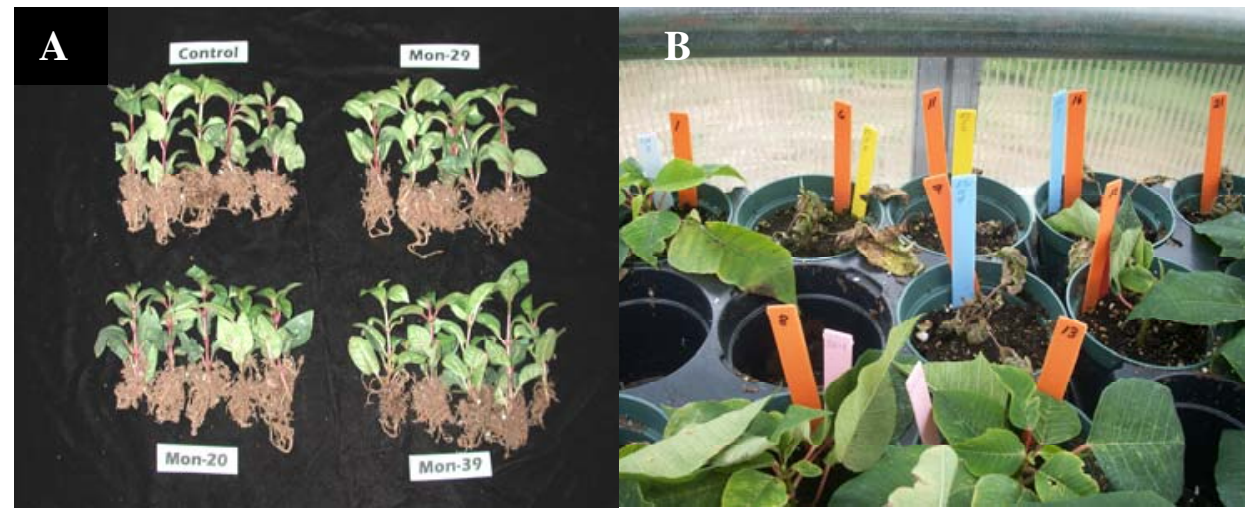

Acknowledgements: This research was sponsored in part by Berger Peat Moss, Ltd., Saint Modeste, Quebec, Canada in cooperation with the Tennessee Agricultural Experiment Station and The University of Tennessee. 


\title{
Seasonal Responses in the Time it Takes for Camellia Twig Blight Symptoms to Develop
}

\author{
W. E. Copes ${ }^{1}$ and J. L. Thomson ${ }^{2}$ \\ ${ }^{1}$ USDA/ARS Southern Horticultural Laboratory, Poplarville, MS 39470 \\ 2 USDA-ARS Southern Regional Research Center, Baton Rouge, LA 70808 \\ ${ }^{1}$ http://www.ars.usda.gov/msa/poplarville
}

Index Words: stem blight, dieback, stem canker

Significance to Industry: In woody stems, infections can develop internally for a while before external symptoms become visible. My goal was to determine the interval between infection and the appearance of camellia twig blight symptoms during different seasons of the year. The information will be used in future research to develop control strategies that prevent infection.

Nature of Work: Individual twigs were wound inoculated monthly on separate sets of container-grown Camellia sasanqua 'Rosea' plants over a 2 year period. Inoculated twigs were monitored every other day for the development of twig blight symptoms. Daily temperature was recorded in 15-minute intervals, using a HOBO H8 Pro Series temperature and relative humidity data logger (Onset, Pocasset, MA). For a set of plants, the test was terminated when all of the inoculated twigs were blighted or most were blighted and no change in symptoms had occurred on the few non-blighted twigs for at least two weeks. When the test was terminated for a set of plants, inoculated twigs were sectioned and plated on potato dextrose agar to recover the causative fungus, Colletotrichum gloeosporioides. The time (in days) until appearance of the initial symptom(s) of disease was modeled using survival analysis methods. Explanatory variables used in the model included a monthly variable, a season variable, and a continuous, time-dependent temperature variable reflecting either the cumulative hours or the mean hours per day within a specified temperature range.

Results and Discussion: We found that the incubation period (time from infection to the initial appearance of a disease symptom) is significantly affected by the number of hours per day that temperature was between 59 and $86^{\circ} \mathrm{F}$. The median incubation period was shortest during spring (18 days) followed by summer ( 23 days). The length of the incubation period was fairly uniform for camellia stems infected monthly from May to September. The median incubation period lengthened significantly when stems were infected during the fall (28 days) and was longest when stems were infected during the winter (57 days).

Although infection was not a natural event in the study, results indicate that twig blight symptoms that develop in April to June could potentially result from infections that occurred as early as February. The primary infection event for $C$. 
gloeosporioides on camellia has been attributed to conidia (asexually produced spores) that infect through fresh leaf scares that result from natural senesce of older leaves in the spring (Baxter 1974, Can et al. 1978). Camellias are broadleaf evergreens that shed older leaves, normally in April to June. The naturally occurring wound is reported to be vulnerable to infection for several days. Stem blight and canker does appear during or shortly after the spring infection period.

Based on differences in the length of incubation periods (being longest during the winter and shortest during the spring), it is possible that infections during the winter months by either ascospores (sexually produced spores) or conidia (asexually produced spores)] could develop slowly without causing symptoms until mid-spring, thus overlapping the appearance of symptoms resulting from infections by conidia through fresh leaf scars during the spring. Periods of warm temperatures, that could be favorable for the development of spores, do occur during the winter months in the gulf coast region. Conidia of Colletotrichum species have been captured from February to November from blighted twigs of other crops in both temperate and tropical climates. Circumstantial evidence from Florida implements the involvement of the sexual stage of $C$. gloeosporioides in the development of strawberry crown rot. No one has attempted to confirm the development of the sexual stage (known as Glomerella cingulata) or the production of conidia on camellia tissue during the winter. Confirming the potential of infection during the winter months could influence timing of early season fungicide applications and cultural practices that increase wounds during that time, such as pruning.

Although the main infection period is believed to be by conidia through new leaf scares, it is highly probable that infection periods might also occur through much of the year and coincide with periods when rainfall occurs intermittently over several days versus just with one stage of the crop (leaf senescence). While a conspicuous amount of twig blight appears in the spring, symptoms (blight, canker, and/or leafspots) can appear during the summer into early fall. When moisture and temperature are favorable, Colletotrichum species can infect healthy plant cells or through wounds made by feeding and egg-laying activities of insects and by pruning and propagation activities of humans.

While we demonstrate seasonal differences in the incubation period associated with the number of hours that temperatures are between 59 and $86^{\circ} \mathrm{F}$, other factors such as stem diameter and cultivar will likely affect the length of the incubation period. Can et al. (1978) observed that incubation periods varied with temperature, by size and age of stems, by camellia cultivar, and by other factors. The results presented here are based upon the use of stems with uniform diameter, which are comparable to incubation periods that would be expected for blight of current year's stems. We suspect that incubation periods likely would be longer for older stems of larger diameter, such as the main trunk. Often cankers and blight of larger diameter stems originate from blight of smaller stems branching off of the larger stem. Future investigations will be required to define seasonal patterns of spore production and dispersal, and what tissues are susceptible to infection at different times of the year. 


\section{Literature Cited:}

1. Baxter, L. W. 1974. Studies on twig blight, canker, and dieback of camellias. American Camellia Yearbook 1974:63-75.

2. Can, N. H. Baxter, L. W., Jr., and Fagan, S. G. 1978. The status of our knowledge in 1978 of twig blight, canker and dieback of camellias caused by a strain of Glomerella cinuglata. American Camellia Yearbook 1978:75-91.

3. Sinclair, W. A., and Lyons, H. H. and Johnson, W. T. 1987. Diseases of trees and shrubs. Comstock Publ. Assoc., Ithaca, NY. 


\title{
‘No Spray’ Rose Cultivars for the Mid South
}

\author{
J. Mynes ${ }^{1}$, M. Windham ${ }^{1}$, A. Windham ${ }^{1}$, Y. Li ${ }^{1}$, W. Copes ${ }^{2}$, and J. Spiers ${ }^{2}$ \\ ${ }^{1}$ University of Tennessee, Knoxville, TN 37996-4560 \\ ${ }^{2}$ Thad Cochran Southern Horticultural Laboratory, Poplarville, MS 39470
}

Key Words: disease resistance, black spot, Cercospora leaf spot, Diplocarpon rosae, Cercospora rosicola

Significance to Industry: In this study, 14 rose cultivars were found with acceptable levels of resistance to both black spot and Cercospora leaf spot. However, resistance claims in catalogs of companies selling roses were not substantiated for many rose cultivars. Caution should be used in purchasing roses based on these claims.

Nature of Work: The popularity of roses as an ornamental is tarnished because of foliar diseases such as black spot (Diplocarpon rosae). A large percentage of consumers will not conform to a spray routine or do not want to use pesticides in their gardens. This aversion to pesticide usage contributes to the popularity of disease resistant roses such as the 'Knock Out' series of shrub roses. Rose companies, recognizing the market potential for disease resistant roses have used colorful terms (remarkable disease resistance, care-free, trouble-free, resists the dreaded fungus, etc) to describe them. The number of roses with resistance claims has exploded since Hagan et al (2) screened 37 cultivars of shrub and grown cover roses for resistance to black spot and Cercospora leaf spot.

Sixty cultivars of roses, most having disease resistance claims associated with their descriptions in rose catalogs, were planted at the West Tennessee Research and Education Center in Spring, 2006. Roses were arranged in a

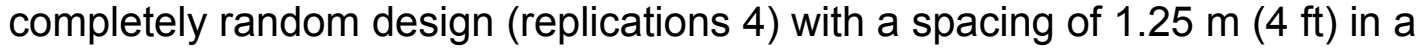
double row with $3.75 \mathrm{~m}(12 \mathrm{ft}$ ) of grass between each double row of roses. After transplanting, plants were watered and mulched. A drip line was installed and plants were watered as needed during the summer. Plants were fertilized with a general 20-20-20 fertilizer at labeled rate once a month until late summer when plants were allowed to harden off. Pruning was only used to prevent one plant from overgrowing an adjacent plant. No fungicides were used in the study. The cultivar 'Peace' served as a control.

Plans were evaluated every two weeks from planting until frost for susceptibility to black spot and Cercospora leaf spot (Cercospora rosicola) using the following scale: $0=$ no symptoms, $1=<2 \%$ of foliage diseased; $2=<10 \%$ of foliage diseased; $3=<25 \%$ of foliage diseased; $4=<50 \%$ of foliage diseased; $5=>$ $50 \%$, but $<100 \%$ of foliage diseased; and $6=100 \%$ of diseased foliage. 
Defoliation was rated using the same scale. Data were analyzed by date and by year using the Proc GLM procedure of SAS. F values for black spot, Cercospora leaf spot and defoliation were considered significant at the 0.05 level. When a significant F-value was detected, cultivars were separated using a LSD means separation test $(p=0.05)$.

Results and Discussion: Black spot was detected four weeks after planting and Cercospora leaf spot was detected at week six. Data for susceptibility to black spot and Cerocospora leaf spot and tolerance to disease (defoliation) for the date August 31 are presented in Table 1. Many rose cultivars with disease resistance claims in industry catalogs were susceptibe to black spot, Cercospora leaf spot or both. Cultivars 'Baby Love', 'Belinda's Dream', 'Carefree Sunshine', 'Fourth of July', 'Hansa', 'Homerun', 'Linda Campbell', 'Palmengarten Farnkfurt', 'Pink Knock Out', 'Red Knock Out', 'Sunsprite', 'Topaz Jewel', 'Wild Spice', and 'Wildberry Breeze' were resistant to both diseases. 'Linda Campbell' (1) and 'Red Knock Out' (2) were found to be susceptible to black spot in previous studies where both cultivars appeared to be resistant in the first year of the studies. In our study, roses will be evaluated for disease resistance again in 2007 and 2008.

As noted in previous studies $(1,2)$, resistance mechanisms for black spot and Cercospora leaf spot appear to be different. The cultivar 'Sea Foam' had no symptoms of black spot (Table 1) but was one of the most susceptible cultivars to Cercospora leaf spot. In contrast, the cultivar 'Be-Bop' was very susceptible to black spot, but was resistant to Cercospora leaf spot. Tolerance to both diseases was observed in the cultivar 'Disneyland Rose' which was statistically as susceptible to both diseases as any other cultivar, but had a relatively low level of defoliation.

Literature Cited:

1. Bir, R.E., T. G. Ranney, and R. K. Jones. 1996. Pest resistant shrub roses: the rest of the story. Southern Nursery Association Research Conference. 41: 278-279.

2. Hagan, A. K., M. E. Rivas-Davila, J. R. Akridge, and J. W. Olive. 2001. Disease resistance of shrub and groundcover roses and the impact of fungicide inputs on those diseases. 
Table 1. Black spot, Cercospora leaf spot and defoliation scores for sixty cultivars of roses.

\begin{tabular}{|c|c|c|c|}
\hline Cultivar & Black spot & Cercospora leaf spot & Defoliation \\
\hline About Face & 2.0 defghi & $0.25 \mathrm{jk}$ & 1.75 fghijklm \\
\hline Baby Love & $0.0 \mathrm{k}$ & $0.0 \mathrm{k}$ & $0.0 \mathrm{~m}$ \\
\hline Ballerina & $0.5 \mathrm{ijk}$ & 1.3 ghij & $0.25 \mathrm{Im}$ \\
\hline Be-Bop & $3.5 \mathrm{abcd}$ & $0.0 \mathrm{k}$ & 3.5 abcdef \\
\hline Belinda's Dream & $0.3 \mathrm{jk}$ & $0.5 \mathrm{ijk}$ & $1.0 \mathrm{ijkm}$ \\
\hline Bill Warriner & $3.3 \mathrm{abcd}$ & $0.0 \mathrm{k}$ & $4.5 \mathrm{a}$ \\
\hline Bonica & 2.3 cdefgh & 0.8 hijk & 2.8 abcdefghi \\
\hline Bride Dream & 2.5 bcdefg & $0.0 \mathrm{k}$ & 2.0 defghijkl \\
\hline Carefree Delight & $0.0 \mathrm{k}$ & $2.5 \mathrm{cdef}$ & 2.0 defghijkl \\
\hline Carefree Sunshine & $0.0 \mathrm{k}$ & 0.8 hijk & $0.0 \mathrm{~m}$ \\
\hline Carefree Wonder & $0.3 \mathrm{jk}$ & $2.5 \mathrm{cdef}$ & 2.8 abcdefghi \\
\hline Cecile Brunner & 0.8 hijk & $1.8 \mathrm{efgh}$ & $1.0 \mathrm{ijklm}$ \\
\hline Crimson Bouget & 3.3 abcde & $0.3 \mathrm{jk}$ & 2.5 bcdefghij \\
\hline Crystal Fairy & $0.0 \mathrm{k}$ & $3.8 \mathrm{ab}$ & 1.8 fghijklm \\
\hline Disneyland Rose & 2.8 abcdef & $1.8 \mathrm{ab}$ & 1.8 fghijklm \\
\hline Fairy Queen & $0.0 \mathrm{k}$ & $3.3 \mathrm{abcd}$ & $1.0 \mathrm{ijklm}$ \\
\hline Fourth of July & 1.5 fghijk & $0.3 \mathrm{jk}$ & 1.8 hijklm \\
\hline Gold Medal & 2.3 cdefgh & $0.0 \mathrm{k}$ & 2.7 abcdefghi \\
\hline Golden Zest & 3.2 abcde & $0.4 \mathrm{ijk}$ & 3.6 abcdef \\
\hline Hansa & $0.3 \mathrm{jk}$ & $0.3 \mathrm{jk}$ & $0.8 \mathrm{jklm}$ \\
\hline Homerun & $0.0 \mathrm{k}$ & $0.3 \mathrm{jk}$ & 1.3 hijklm \\
\hline Honor & $3.7 \mathrm{abc}$ & $0.0 \mathrm{k}$ & 3.0 abcdefgh \\
\hline Julia Child & $4.0 \mathrm{ab}$ & $0.0 \mathrm{k}$ & 3.3 abcdefg \\
\hline Linda Campbell & 1.5 fghijk & 0.8 hijk & 1.3 hijklm \\
\hline Love & 2.0 defghi & $0.5 \mathrm{ijk}$ & 2.0 defghijkl \\
\hline Lovely Fairly & $0.0 \mathrm{k}$ & $3.3 \mathrm{abcd}$ & 1.0 kjklm \\
\hline Magic Blanket & $0.0 \mathrm{k}$ & $2.5 \mathrm{cdef}$ & $0.5 \mathrm{klm}$ \\
\hline Magic Carousel & 0.8 hijk & 1.5 fghi & 1.5 ghijklm \\
\hline Memorial Day & 3.3 abcde & $0.0 \mathrm{k}$ & 3.3 abcdefg \\
\hline Midas Touch & 2.0 defghi & $0.5 \mathrm{ijk}$ & 2.5 bcdefghij \\
\hline Nearly Wild & 0.8 hijk & $3.5 \mathrm{abc}$ & 1.5 ghijklm \\
\hline Olympiad & $3.5 \mathrm{abcd}$ & $0.0 \mathrm{k}$ & $4.0 \mathrm{abc}$ \\
\hline Palmengarten Frankfort & 1.5 fghijk & $0.5 \mathrm{ijk}$ & 3.4 abcdef \\
\hline Pascali & 2.6 bcdef & 0.8 hijk & 3.4 abcdef \\
\hline Peace & $4.3 \mathrm{a}$ & $0.0 \mathrm{k}$ & $4.0 \mathrm{abc}$ \\
\hline Pink Knock Out & $0.0 \mathrm{k}$ & $0.3 \mathrm{k}$ & 2.0 defghijkl \\
\hline Pretty Lady & $0.0 \mathrm{k}$ & 1.0 hijk & $0.8 \mathrm{jklm}$ \\
\hline Pristine & 3.0 abcdef & $0.0 \mathrm{k}$ & $0.8 \mathrm{jklm}$ \\
\hline
\end{tabular}


Table 1 (continued). Black spot, Cercospora leaf spot and defoliation scores for sixty cultivars of roses.

\begin{tabular}{llcc} 
Cultivar & Black spot & Cercospora leaf spot & Defoliation \\
\hline Rainbow's End & $3.3 \mathrm{abcde}$ & $0.5 \mathrm{isk}$ & $3.0 \mathrm{abcdefgh}$ \\
Red Knock Out & $0.0 \mathrm{k}$ & $0.6 \mathrm{ijk}$ & $1.9 \mathrm{efgh}$ \\
Red Ribbons & $1.8 \mathrm{efghij}$ & $0.8 \mathrm{hijk}$ & $3.5 \mathrm{abcdef}$ \\
Santa Claus & $2.0 \mathrm{defghi}$ & $0.7 \mathrm{ijk}$ & $1.5 \mathrm{ghijklm}$ \\
Scent From Above & $2.8 \mathrm{abcdef}$ & $0.3 \mathrm{jk}$ & $3.0 \mathrm{abcdefgh}$ \\
Scentimental & $4.0 \mathrm{ab}$ & $0.0 \mathrm{k}$ & $3.8 \mathrm{abcdefgh}$ \\
Sea Foam & $0.0 \mathrm{k}$ & $4.0 \mathrm{a}$ & $1.5 \mathrm{ghijklm}$ \\
Sexy Rexy & $2.5 \mathrm{bcdefg}$ & $0.0 \mathrm{k}$ & $3.8 \mathrm{abcde}$ \\
Snowcone & $0.0 \mathrm{k}$ & $2.3 \mathrm{defg}$ & $0.5 \mathrm{k}$ \\
Space Odyssey & $2.8 \mathrm{abcdef}$ & $0.3 \mathrm{jk}$ & $4.0 \mathrm{abc}$ \\
Starina & $3.8 \mathrm{abc}$ & $0.5 \mathrm{ijk}$ & $3.0 \mathrm{abcdefgh}$ \\
Sunbright & $4.3 \mathrm{a}$ & $0.3 \mathrm{jk}$ & $2.0 \mathrm{defghijkl}$ \\
Sunsprite & $1.5 \mathrm{fghijk}$ & $0.0 \mathrm{k}$ & $1.0 \mathrm{jjklm}$ \\
Topaz Jewel & $0.5 \mathrm{jik}$ & $0.5 \mathrm{ijk}$ & $0.8 \mathrm{jklm}$ \\
Tournament of Roses & $3.3 \mathrm{abcde}$ & $0.5 \mathrm{ijk}$ & $3.0 \mathrm{abcdefgh}$ \\
White Dawn & $0.0 \mathrm{k}$ & $1.8 \mathrm{efgh}$ & $0.8 \mathrm{jklm}$ \\
Wild Spice & $0.0 \mathrm{k}$ & $0.0 \mathrm{k}$ & $0.0 \mathrm{~m}$ \\
Wild Thing & $0.9 \mathrm{ghijk}$ & $2.7 \mathrm{bcde}$ & $1.9 \mathrm{efghijkl}$ \\
Wildberry Breeze & $0.0 \mathrm{k}$ & $0.5 \mathrm{ijk}$ & $0.8 \mathrm{jklm}$ \\
Winsome & $2.8 \mathrm{abcdef}$ & $0.3 \mathrm{defg}$ & $2.0 \mathrm{defghijkl}$ \\
Zephrine Drouhin & $4.3 \mathrm{a}$ & $0.3 \mathrm{jk}$ & $4.3 \mathrm{ab}$ \\
& & &
\end{tabular}




\title{
Resistance to Powdery Mildew in Hydrangeas
}

\author{
Yonghao $\mathrm{Li}^{1}$, Mark T. Windham ${ }^{1}$, Margaret T. Mmbaga ${ }^{2}$, Robert N. Trigiano ${ }^{1}$, \\ Alan S. Windham ${ }^{1}$, Sandra M. Reed ${ }^{3}$, James M. Spiers ${ }^{4}$, \\ and Timothy A. Rinehart ${ }^{4}$ \\ ${ }^{1}$ Dept. of Entomology and Plant Pathology, University of Tennessee, \\ Knoxville, TN 37996-4560 \\ ${ }^{2}$ Nursery Research Center, Tennessee State University, McMinnville, TN 37110 \\ ${ }^{3}$ USDA/ARS Floral \& Nursery Plants Research Unit, McMinnville, TN 37110 \\ ${ }^{4}$ USDA/ARS Small Fruit Research Unit, Poplarville, MS 39470
}

mwindham@utk.edu

Index Words: Erysiphe polygoni, infection process, resistance components

Significance to Industry: Powdery mildew is an important foliar disease of hydrangeas. For developing efficient integrated disease management strategies involving the utilization of resistant cultivars, it is essential to understand how the powdery mildew fungus infects hydrangea plants and how the host resists the parasitism by the fungus. This paper describes the infection process of Erysiphe polygoni and investigated the effects of hydrangea susceptibility to powdery mildew development using a leaf disk assay. Results of these experiments could be used to develop laboratory screening methods for evaluating hydrangea resistance to powdery mildew.

Nature of Work: Powdery mildew, caused by E. polygoni, is an important foliar disease of hydrangeas. Plants grown in greenhouses or under shade are particularly susceptible to powdery mildew (3). Variation of resistance to $E$. polygoni among hydrangea species and cultivars has been noted in greenhouses and gardens (1). In order to understand infection process of E. polygoni, leaf disks of Hydrangea macrophylla 'Nikko Blue' were inoculated with diseased hydrangea leaves in a settling tower as described previously (2). Spore germination and fungal development were observed in a time series using fluorescence and light microscopy after inoculated leaf disks were stained. To compare variation of the fungal development among cultivars, leaf disks of six hydrangea cultivars, 'Forever Pink', Holstein', 'Lilacina', 'Madame Emile Mouilliere', 'Nikko Blue' and 'Veitchii', were inoculated in the settling tower. Inoculated leaf disks were placed on two layers of moist filter papers in petri dishes and incubated at $21 \pm 1{ }^{\circ} \mathrm{C}$ with a continuous photoperiod. Percent germinated conidia with the secondary germ tube were assessed on cleared and stained leaf disks at 2 days after inoculation (DAl) using a compound microscope. Infection efficiency was defined as the percentage of inoculated conidia that formed branched hyphae at 7 DAl. The numbers of powdery mildew colonies were counted under a stereo microscope and the infection efficiency was calculated. Latent period was defined as the time at which conidiophores 
and conidia were observed on inoculated leaf disks. Sporulation was defined as the number of conidia produced on a leaf disk $(1.2 \mathrm{~cm}$ in diameter) at $11 \mathrm{DAl}$. All experiments were repeated four times with three leaf disks in each experiment.

Results and Discussion: On hydrangea cultivar 'Nikko Blue', conidia of $E$. polygoni germinated and formed primary appressoria within $6 \mathrm{~h}$ after inoculation (HAl). Secondary germ tubes were initiated from conidium body and the primary appressoria at $12 \mathrm{HAl}$ and $24 \mathrm{HAl}$, respectively. Secondary germ tubes elongated to form hyphae with lateral appressoria. Branched hyphae formed at $72 \mathrm{HAl}$. Conidiophores and conidia were observed on fungal colonies at $120 \mathrm{HAl}$.

Significant differences in fungal development on leaf disks were detected among hydrangea cultivars. In this study, cultivar 'Veitchii' and 'Holstein' showed higher levels of resistance to powdery mildew than the other four cultivars, Resistance response to powdery mildew in 'Veitchii' and 'Holstein' was manifested as significantly fewer germinated conidia with secondary germ tube, lower value of infection efficiency, delayed latent period and less sporulation. However, sporulation of powdery mildew on cultivar 'Holstein' was not significantly different from those on the susceptible or intermediate cultivars. Cultivars 'Madame Emile Mouilliere' and 'Lilacina' had higher values of percent germinated conidia with secondary germ tube and infection efficiency than 'Nikko Blue' and 'Forever Pink', but there were no significant differences in latent period and sporulation among these four cultivars.

The results of infection process and resistance components in the present paper could provide important information for investigating epidemiology powdery mildew and develop rapid and efficient methods to screen hydrangeas for resistance to the disease.

\section{Literature Cited:}

1. Dirr, M. 2004. Hydrangeas for American Gardens. Timber Press, Inc. Portland OR.

2. Li, Y.H., Windham, M.T., Trigiano, R.N., Fare, D.C., Spiers, J.M., and Copes, W.E. 2005. Spore germination, infection structure formation and colony development of Erysiphe pulchra on dogwood leaves and glass slides. Plant Dis. 89: 1301-1305.

3. Williams-Woodward, J. L., and Daughtrey, M. L. 2001. Hydrangea diseases. Pages 191-194 in Diseases of Woody Ornamentals and Trees in Nurseries. Eds. Jones, R. K., and Benson, D. M. APS Press St Paul, MN. 


\title{
Fungicide Efficacy for Control of Daylily Rust
}

\author{
Stephen R. Vann ${ }^{1}$ and James A. Robbins ${ }^{2}$ \\ University of Arkansas \\ ${ }^{1}$ Dept. of Plant Pathology and ${ }^{2}$ Dept. of Horticulture, Little Rock, AR 72203 \\ svann@uaex.edu
}

Index words: Puccinia hemerocallidis Thuemen, fungicide, plant disease

Significance to the Industry: Selected fungicides were screened for the control of daylily rust on various daylily cultivars in a commercial operation in central Arkansas. The trial was initiated on mature clumps of daylily (Hemerocallis) at a local field grower to evaluate the effectiveness and application methods for control. When compared to the other fungicide treatments and control plants, both Heritage 50WDG and Bayleton 50WSP provided good control when applied as a foliar spray to the selected daylily cultivars. Foliar applications beginning after cutback provided best results when compared to non-cutback. Both Heritage and Bayleton fungicides provided best control when applied as a preventative rather than a curative application.

Nature of Work: Daylily rust (Puccinia hemerocallidis) was first identified in Arkansas in August 2001. Growing resistant daylily cultivars is the best method to manage the daylily rust fungus. Based on a prior study (2) in Arkansas, the susceptibility of daylily cultivars varies greatly. Since a large number of cultivars were identified as having some degree of susceptibility, the use of fungicides may be of benefit to the nursery industry when growing those particular cultivars that have desirable flower traits to the customer. Fungicides may serve to protect those susceptible cultivars from rust infection or reduce the severity of the disease.

Five separate blocks of mature daylily clumps were used in the experiment. Each block consisted of at least 30 clumps of daylily cultivars that were severely infected with daylily rust. Daylilies were grown in full sun in 6' wide beds mulched with pine straw and irrigated from overhead. Space between rows of mature daylilies was 14". Fungicide solutions were prepared using tap water at rates shown in Table 1. Treatment solutions were applied on 4 September 2001 in the morning under clear skies using a hand-held pump sprayer. Solutions were applied until run-off. A water control was not included in this experiment. To prevent spray overlap, a 4' $\times$ 8' sheet of plywood was placed between plant rows. Treatment solutions were re-applied on September 11 and 25 at the same rate and method as for the first application.

For 3 of the 5 blocks of daylilies the foliage was not cut back. Those cultivar blocks that were not cut-back include: 'Creole Blush', 'Sepal Streaker', and 'Wedding Band'. In the remaining two blocks ('Double Pink Treasure' and 
'Bahama Ripples') the foliage on one-half of the plants was cut back to the ground on 5 September. Following the removal of this previously treated foliage, the 'stumps' were re-treated with the same chemical in the same manner as used the previous day. Daylily plants were evaluated by the same plant pathologist at each rating date using a scale that visually estimated the percentage of leaf surface area infected with daylily rust (Table 2-6). Plants were rated on a scale of $0-5$ based on the percentage of leaf surface area covered with rust pustules: $0=$ no rust ; $1=<20 \% ; 2=21-40 \% ; 3=41-60 \%, 4=61-80,5=81-100 \%$. For those plants that were not cut-back, the chemical treatments were evaluated as to their effectiveness as curative chemicals. Since new 'non-infected' foliage would emerge from the treated foliage 'stumps', chemicals were evaluated as to their effectiveness as preventative chemicals with this treatment.

Foliage was rated on 9/11/01 for phytotoxic symptoms on a scale of $0-10(0=$ none and $10=$ severe) in Table 7 . While some phytotoxic symptoms were observed on one cultivar ('Double Pink Treasure'), the symptoms were minimal and did not last for more than one week.

Results and Discussion: Under Arkansas field conditions, our results suggest that Bayleton and Heritage are the most effective chemicals for preventative control of daylily rust. The most effective chemical for curative treatment of daylily rust was Bayleton. Since Bayleton is not currently labeled for daylily, Heritage would be useful as a suitable alternative. Temporary leaf phytotoxicity was noted on "Double Pink Treasure" following the application of Phyton 27 and Banner Maxx. Similar to recommendations in other states (1), the most effective treatment is to cut the plants back and then apply preventative fungicides according to label directions. Complete plant coverage with an appropriate fungicide in conjunction with good sanitation is essential in a successful control program.

\section{Literature Cited:}

1. Buck, J. W. and Williams-Woodward, J.L. 2002. Efficacy of Fungicide Treatments for Control of Daylily Rust. The Daylily Journal 57: 53-59.

2. Vann, S. R. and J. A. Robbins. 2006. Susceptibility of Daylily Cultivars to Daylily Rust in Arkansas. Proc. SNA Res. Conf, 51: 197-200. 
Table 1. Fungicide treatments

\begin{tabular}{|l|l|l|}
\hline \multicolumn{1}{|c|}{ Trade Name } & \multicolumn{1}{|c|}{ Formulation } & \multicolumn{1}{c|}{ Concentration } \\
\hline Banner Maxx & $14.3 \%$ lc & 6 oz product $100 \mathrm{gal}$ \\
\hline Bayleton & $50 \%$ WSP & $5.5 \mathrm{oz} / 80 \mathrm{gal}$ \\
\hline Systhane & $40 \%$ WSP & $2 \mathrm{oz} / 50 \mathrm{gal}$ \\
\hline Heritage & $50 \%$ WDG & $2 \mathrm{oz} / 100 \mathrm{gal}$ \\
\hline Phyton 27 & $21.4 \% \mathrm{lc}$ & $2.5 \mathrm{oz} / 10 \mathrm{gal}$ \\
\hline
\end{tabular}

Table 2. Foliar ratings ${ }^{z}$ on two dates for daylily rust on mature clumps of 'Double Pink Treasure'. Foliage was either cut-back or not on 9/5/01.

The initial rating on $9 / 4$ was 2.8 .

\begin{tabular}{|l|c|c|c|c|}
\hline & \multicolumn{2}{|c|}{$9 / 11 / 01$} & \multicolumn{2}{c|}{$10 / 5 / 01$} \\
\hline Cut back & $\begin{array}{c}\text { Not cut } \\
\text { back }\end{array}$ & Cut back & $\begin{array}{c}\text { Not cut } \\
\text { back }\end{array}$ \\
\hline Syyleton & 0 & 1.8 & 1 & 2 \\
\hline Heritage & 0 & 3 & 1 & 2.5 \\
\hline Phyton 27 & 0 & 2.2 & 2.5 & 2.5 \\
\hline $\begin{array}{l}\text { Banner } \\
\text { Maxx }\end{array}$ & 0 & 3 & 1 & 3 \\
\hline
\end{tabular}

$z \%$ of leaf surface area with rust pustules: ( $0=$ none; $1=$ $<20 \%$; 2=21-40\%; 3=41-60\%, 4=61-80, 5=81-100\%).

Table 3. Foliar ratings ${ }^{z}$ on two dates for daylily rust on mature clumps of 'Bahama Ripples'. Foliage was either cut-back or not on 9/5/01. The initial rating on $9 / 4$ was 2.8 .

\begin{tabular}{|l|c|c|c|c|}
\hline & \multicolumn{2}{|c|}{$9 / 11 / 01$} & \multicolumn{2}{c|}{$10 / 5 / 01$} \\
\hline Cut back & $\begin{array}{c}\text { Not cut } \\
\text { back }\end{array}$ & Cut back & $\begin{array}{c}\text { Not cut } \\
\text { back }\end{array}$ \\
\hline Bayleton & 0 & 2 & 1 & 2 \\
\hline Systhane & 0 & 1.8 & 1.5 & 3 \\
\hline Heritage & 0 & 3 & 1 & 3 \\
\hline Phyton 27 & 0 & 2.1 & 2 & 3.5 \\
\hline $\begin{array}{l}\text { Banner } \\
\text { Maxx }\end{array}$ & 0 & 1.5 & 1.5 & 3 \\
\hline
\end{tabular}

$\mathrm{Z} \%$ of leaf surface area with rust pustules: $(0=$ none; $1=$ $<20 \%$; 2=21-40\%; 3=41-60\%, 4=61-80, 5=81-100\%). 
Table 4. Foliar ratings ${ }^{z}$ on three dates for daylily rust on mature clumps of 'Creole Blush'. The initial rating on 9/4 was 4.2.

\begin{tabular}{|l|c|c|}
\hline & $9 / 11 / 01$ & $10 / 5 / 01$ \\
\hline Bayleton & 3.2 & 3 \\
\hline Systhane & 3.8 & 4 \\
\hline Heritage & 3.8 & 3.5 \\
\hline Phyton 27 & 3.8 & 4 \\
\hline $\begin{array}{l}\text { Banner } \\
\text { Maxx }\end{array}$ & 3.5 & 4 \\
\hline
\end{tabular}

$z \%$ of leaf surface area with rust pustules: $(0=$ none; $1=<20 \%$; $2=21-40 \%$; 3=41-60\%, 4=61-80, $5=81-100 \%)$.

Table 5. Foliar ratings ${ }^{Z}$ on three dates for daylily rust on mature clumps of 'Sepal Streaker'. The initial rating on 9/4 was 3.7.

\begin{tabular}{|l|c|c|}
\hline & $9 / 11 / 01$ & $10 / 5 / 01$ \\
\hline Bayleton & 3.2 & 3 \\
\hline Systhane & 3.5 & 2.5 \\
\hline Heritage & 3.6 & 2.5 \\
\hline Phyton 27 & 3.5 & 2.5 \\
\hline $\begin{array}{l}\text { Banner } \\
\text { Maxx }\end{array}$ & 3 & 4 \\
\hline
\end{tabular}

$z \%$ of leaf surface area with rust pustules: ( $0=$ none; $1=<20 \%$; $2=21$ $40 \%$; $3=41-60 \%, 4=61-80,5=81$ $100 \%)$.

Table 6. Foliar ratings ${ }^{z}$ on three dates for daylily rust on mature clumps of 'Wedding Band'. The initial rating on 9/4 was 3.7.

\begin{tabular}{|l|c|c|}
\hline & $9 / 25 / 01$ & $10 / 5 / 01$ \\
\hline Bayleton & 2 & 2.5 \\
\hline Systhane & 2.5 & 3.5 \\
\hline Heritage & 2.5 & 2.5 \\
\hline Phyton 27 & 2.5 & 3.5 \\
\hline $\begin{array}{l}\text { Banner } \\
\text { Maxx }\end{array}$ & 3 & 3.5 \\
\hline
\end{tabular}

Z\% of leaf surface area with rust

pustules: $(0=$ none; $1=<20 \%$;

$2=21-40 \% ; 3=41-60 \%, 4=61-80$, $5=81-100 \%)$. 
Table 7. Foliar phytotoxic rating for mature daylily clumps on 9/11/01.

\begin{tabular}{|l|c|c|c|c|c|}
\hline & $\begin{array}{c}\text { 'Double } \\
\text { Pink } \\
\text { Treasure' }\end{array}$ & $\begin{array}{c}\text { 'Bahama } \\
\text { Ripples' }\end{array}$ & $\begin{array}{c}\text { 'Creole } \\
\text { Blush' }\end{array}$ & $\begin{array}{c}\text { 'Wedding } \\
\text { Band' }\end{array}$ & $\begin{array}{c}\text { 'Sepal } \\
\text { Streaker' }\end{array}$ \\
\hline Bayleton & 1.5 & 0 & 0 & 0 & 0 \\
\hline Systhane & 1 & 0 & 0 & 0 & 0 \\
\hline Heritage & 2 & 0 & 0 & 0 & 0 \\
\hline Phyton 27 & 4 & 0 & 0 & 0 & 0 \\
\hline $\begin{array}{l}\text { Banner } \\
\text { Maxx }\end{array}$ & 3.5 & 0 & 0 & 0 & 0 \\
\hline
\end{tabular}




\title{
Adaptability and Reaction of Cleyera Selections to a Leaf Spot Disease
}

\author{
A. K. $\operatorname{Hagan}^{1}$ and J. R. Akridge ${ }^{2}$ \\ ${ }^{1}$ Department of Entomology and Plant Pathology \\ Auburn University, AL 36849 \\ ${ }^{2}$ Brewton Agricultural Research Unit, Brewton, AL 36427
}

Index Words: Cercospora leaf spot, Ternstroemia gymnanthera

Significance to Industry: Cleyera is a hardy, nearly pest-free evergreen shrub that is an attractive alternative to the red-tip photinia. Cercospora leaf spot is a relatively common late winter to early spring disease in landscape plantings of 'seedling' cleyea. While this disease probably has little impact on overall plant health, the noticeable leaf spotting and premature defoliation can be unsightly. Several newly released, cutting propagated cleyera cultivars were usually less susceptible to Cercospora leaf spot than 'seedling' cleyera. The cleyera cv. LeAnn suffered the least leaf spotting and was the most attractive of the newly released cleyera cultivars evaluated in this simulated landscape planting in South Alabama.

Nature of Work: Cleyera (Ternstroemia gymnanthera) is a hardy medium to large upright evergreen shrub with dense, dark green leaves, fragrant white flowers, and globose yellow to red fruit that can be used in foundation, border, hedge, and specimen plantings in home and commercial landscapes throughout Alabama. While cleyera is best adapted to partially shaded sites, it does reasonably well in full sun (1). Dirr (1) noted that leaves of plants in full sun are often discolored. Until recently, nearly cleyera in the trade were propagated from seed. As a result, considerable differences in leaf color and growth habit were often seen in large cleyera plantings. Recently, cutting-propagated cultivars, such as Bronze Beauty, Bigfoot, and LeAnn have been released.

When compared with many other shrubs, cleyera is largely free of damaging diseases. In Alabama, a leaf spot disease, which is caused by the fungus Cercospora sp., is occasionally found on 'seedling' cleyera. Small brown spots first appear on the mature leaves at the base of the plant in mid- to late winter. Large red to purple blotches often surround the spots on the upper leaf surface. Heavily spotted leaves often turn bright red before they fall to the ground. Leaf spotting starts in the lower limbs and gradually moves upward into the middle of the canopy of susceptible cleyera. By early to mid-spring, diseased cleyera may loose upwards of $30 \%$ or more of their leaf canopy. While Cercospora leaf spot will not kill cleyera, partially defoliated plants are unattractive and the fallen leaves are unsightly. 
Before planting, soil fertility and $\mathrm{pH}$ of a Benndale (A) fine sandy loam soil at the Brewton Experiment Field in Brewton, Alabama (USDA Hardiness Zone 8a) were adjusted according to the results of a soil fertility assay done be the Auburn University Soil Testing Laboratory. The simulated landscape planting included five two-plant replications of Leann, Copper Crown, Regal, Bronze Beauty, Big Foot and 'seedling' cleyera that were planted on 8-ft centers in rows spaced $10 \mathrm{ft}$ apart. Plants were watered as needed with a drip irrigation system. Beds were mulched with aged pine bark. Each spring, Osmocote 17-7-12 slow-release fertilizer was evenly spread around the base of each plant. A directed application of $1 \mathrm{lb} / \mathrm{A}$ of Gallery DF and $2 \mathrm{qt} / \mathrm{A}$ of Surflan T/O was made in mid-February in each year to the mulched beds to control annual weeds. Escape weeds were pulled by hand or controlled with spot applications of 912 Herbicide 6S (MSMA). The centipedegrass alleys between the rows were periodically mowed.

In 2003, 2004, and 2005, Cercospora leaf spot levels were rated using a modified 1 to 10 Florida peanut leaf spot rating scale where $1=$ no disease, 2 = very few spots on leaves in lower canopy, $3=$ light leaf spotting in lower and upper plant canopy, $4=$ some leaf spotting in lower and upper canopy with $\leq$ $10 \%$ leaf loss, $5=$ leaf spotting noticeable in canopy with $\leq 25 \%$ leaf loss, $6=$ leaf spotting heavy with $\leq 50 \%$ leaf loss, $7=$ leaf spotting very heavy with $\leq 75 \%$ leaf loss, $8=$ leaf spots numerous on most remaining leaves with $\leq 90 \%$ leaf loss, $9=$ few remaining leaves covered with spots with $\leq 95 \%$ leaf loss, and $10=$ plants 100\% defoliated on 19 March 2003, 25 March 2004, and 22 April 2005. The extent of sun scald was also assessed on 22 April 2005 on a 1 to 10 scale, which was based on the percentage of leaves discolored.

Results and Discussion: Significant differences in Cercospora leaf spot ratings were noted between the 'seedling' and other cleyera cultivars in 2003 (Table 1). Noticeable leaf spotting as well as an average of $10 \%$ premature leaf shed was seen on the 'seedling' cleyera. The level of leaf spotting, however, was not the same on the individual 'seedling' cleyera. While premature leaf loss on many plants reached $25 \%$, a few of the 'seedling' cleyera remained largely free of leaf spot symptoms. A low level of leaf spotting was seen on the other cleyera cultivars.

Cercospora leaf spot ratings for the 'seedling' cleyera were slightly lower in 2004 than in 2003. While some leaf spotting in the lower and middle canopy was seen, the level of premature leaf loss was low (Table 1). The leaf spot rating for cleyera cv. Big Foot was slightly lower compared with that of the 'seedling' cleyera. A low level of leaf spot development was also seen on the cleyera cv. Copper Crown. Regal, LeAnn, and Bronze Beauty were free of leaf spot symptoms.

In contrast to the results seen in the previous two years, noticeable leaf spotting was seen not only the 'seedling' cleyera as well as the cultivars Copper Crown, Regal, Bronze Beauty, and Big Foot in 2005 (Table 1). Cercospora leaf spot 
ratings for Copper Crown and Copper Crown were slightly below those for Big Foot and the 'seedling cleyera'. In contrast to the above cultivars, LeAnn remained free of Cercospora leaf spot.

Sun scald was characterized by a yellowing or chlorosis of the leaves as well as the appearance of pin point sized purple spots that were sometimes surrounded by a light purple starburst line pattern. No brown or dead tissue was seen in the center of these tiny purple spots. In April 2005, this leaf spotting pattern was largely confined to the southeast and southern exposure. Bronze Beauty suffered much heavier leaf discoloration compared with the other cleyera cultivars. The least leaf scald was seen on the 'seedling cleyera'.

While the level of damage differed from plant to plant, noticeable leaf spotting as well as a low level of premature leaf shed was seen in all three years on the 'seedling' cleyera. Cercospora leaf spot ratings for cleyera cv. Big Foot, which increased from 1.4 in 2003 to 4.0 in 2005, were eventually similar to the ratings of the 'seedling' cleyera. A noticeable increase in leaf spotting was also seen between 2004 and 2005 on Copper Crown, Regal, and Bronze Beauty cleyera. Over the three-year test period, LeAnn cleyera remained free of Cercospora leaf spot. In addition to Cercospora leaf spot, considerable winter sun scald was seen on Bronze Beauty in 2005. Some sun scald was also seen on the cleyera cultivars. Due in part to the absence of Cercospora leaf spot and low level of sunscald in 2005 , the most attractive cleyera in this simulated landscape planting was LeAnn.

\section{Literature Cited:}

1. Dirr, M. A. 1998. Manual of Woody Landscape Plants. $5^{\text {th }}$ ed., Stipes Publishing Co., Champaign, IL.

Table 1. Reaction of cleyera cultivars to Cercospora leaf spot and sun scald.

\begin{tabular}{llclc} 
& \multicolumn{3}{c}{ Disease Rating } \\
Cleyera Selection & 2003 & 2004 & 2005 & Sun Scald* \\
LeAnn & $1.1 \mathrm{~b}^{\star *}$ & $1.0 \mathrm{~b}$ & $1.0 \mathrm{c}$ & $2.3 \mathrm{bc}$ \\
Copper Crown & $1.2 \mathrm{~b}$ & $1.7 \mathrm{~b}$ & $3.0 \mathrm{ab}$ & $2.2 \mathrm{~cd}$ \\
Regal & $1.1 \mathrm{~b}$ & $1.0 \mathrm{~b}$ & $3.1 \mathrm{ab}$ & $1.8 \mathrm{~cd}$ \\
Bronze Beauty & $1.2 \mathrm{~b}$ & $1.0 \mathrm{~b}$ & $3.3 \mathrm{ab}$ & $4.8 \mathrm{a}$ \\
Big Foot & $1.4 \mathrm{~b}$ & $2.5 \mathrm{a}$ & $4.0 \mathrm{a}$ & $2.7 \mathrm{~b}$ \\
'Seedling' & $4.0 \mathrm{a}$ & $3.1 \mathrm{a}$ & $3.7 \mathrm{ab}$ & $1.5 \mathrm{~d}$
\end{tabular}

*Sun scald rated on 22 April 2005.

${ }^{* *}$ Means followed by the same letter are not significantly different according to Fisher's least significant difference test $(P=0.05)$. 


\title{
Fungicides compared for the control of Cercospora leaf spot on crapemyrtle
}

\author{
A. K. $\operatorname{Hagan}^{1}$ and J. R. Akridge ${ }^{2}$ \\ ${ }^{1}$ Department of Entomology and Plant Pathology \\ Auburn University, AL 36949 \\ ${ }^{2}$ Brewton Agricultural Research Unit, Brewton, AL 36427
}

Index Words: Lagerstroemia indica, Cercospora lythracearum, 3336 4.5F, fertiloam Liquid Systemic Fungicide, Bayer Advanced Disease Control for Roses, Flowers \& Shrubs, SA Systemic Fungicide, Neem Concentrate, Immunox, fertiloam Blackspot and Powdery Mildew Control, Heritage 50W, SunSpray Ultra Fine Oil.

Significance to Nursery Industry: Cercospora leaf spot is not as well recognized as powdery mildew as a damaging disease of crapemyrtle. Defoliation on susceptible cultivars is often so heavy that their fall color display is greatly diminished. Fungicides are a possible control option, particularly on susceptible plants in high visibility landscape or commercial plantings. Best control of Cercospora leaf spot was obtained with bimonthly applications of the retail fungicides Bayer Advanced Disease Control for Roses, Flowers, and Shrubs, Spectracide Immunox, and ferti-loam Liquid Systemic Fungicide as well as the commercial fungicides Heritage 50W and Cleary's 3336 4.5F. SunSpray Ultra Fine Oil also gave good disease control in one of two years. When compared with the above fungicides, Neem Concentrate and to a lesser extent SA Systemic Fungicide were ineffective.

Nature of Work: Brilliant fall color, handsome exfoliating bark, lush green foliage, and showy flower panicles have made crapemyrtle a fixture in Southern landscapes (1). While powdery mildew is considered the most damaging disease of crapemyrtle, Cercospora leaf spot is more common and may often have a greater impact of tree aesthetics in residential and commercial plantings. The most notable symptom of this disease is the premature defoliation that largely eliminates the brilliant fall foliage color display for which crapemyrtle are known. Although a few hybrid crapemyrtle cultivars have good resistance to Cercospora leaf spot, susceptible cultivars or L. indica 'seedlings' are far more common in residential and commercial plantings (4). On the leaf spot susceptible cultivars, fungicides are a possible control option, particularly in highly visible plantings of crapemyrtle.

While leaf spot diseases caused by Cercospora-type fungi are fairly common on woody ornamentals, relatively few trials have focused on identifying fungicides that effectively control these diseases. Previously, Hagan and Akridge (2) 
obtained good control of Cercospora leaf spot on shrub rose with bimonthly applications with Compass 50W, Heritage 50W, and Eagle 40W. Daconil Ultrex also gave better disease control when applied at 1- than 2-week intervals. When applied bimonthly, Eagle 40W, Immunox, Cleary's 3336 4.5F, and Liquid Systemic Fungicide also proved effective in controlling Cercospora leaf spot on flowering dogwood (3). Williams-Woodward and Buck (5) noted that Fore and Daconil Ultrex gave the best control of Cercosporidium needle blight on Leyland cypress. The objective of this study was to compare the efficacy of selected offthe-shelf retail as well as two commercial fungicide formulations for the control of Cercospora leaf spot on crapemyrtle in a simulated landscape planting.

The test site was worked to seed-bed condition and $400 \mathrm{lb} / \mathrm{A}$ of 13-13-13 fertilizer was incorporated. The crapemyrtle cultivar 'Wonderful White', which is highly susceptible to Cercospora leaf spot (4), was transplanted on 23 March 2005 into a Benndale sandy loam soil ( $\leq 1 \%$ organic material) at the Brewton Agricultural Research Unit (USDA Hardiness Zone 8a). Prior to planting, pH was adjusted according to the results of a soil fertility assay. A drip irrigation system was installed at planting and the trees were watered as needed. In April each year, approximately $0.45 \mathrm{lb}$ of 17-7-12 Osmocote fertilizer was uniformly distributed around each plant. A tank-mixture of the pre-emergent herbicides Gallery at 1 $\mathrm{Ib} / \mathrm{A}$ and Surflan $\mathrm{T} / \mathrm{O}$ at $2 \mathrm{qt} / \mathrm{A}$ was broadcast in late winter or early spring to control annual weeds. Finale at $2 \mathrm{fl} \mathrm{oz}$ per gal was applied as needed for postemergence grass control. Escape weeds were pulled by hand. A randomized complete block design with four single-plant replications was used. Fungicide treatments were applied at 2-week intervals from 15 June to 22 July 2005 and from 21 June to 16 August 2006. Cercospora leaf spot (CLS) incidence and defoliation were visually rated on 2 July, 24 August, 5 October, and 25 October 2005 and 24 July, 31 August, and 27 September 2006 using the 1 to 10 modified Florida peanut leaf spot rating scale where $1=$ no disease, $2=$ very few spots on leaves in lower canopy, 3 = light leaf spotting in lower and upper plant canopy, 4 $=$ some leaf spotting in lower and upper canopy with $\leq 10 \%$ leaf loss, $5=$ leaf spotting noticeable in canopy with $\leq 25 \%$ leaf loss, $6=$ leaf spotting heavy with $\leq$ $50 \%$ leaf loss, $7=$ leaf spotting very heavy with $\leq 75 \%$ leaf loss, $8=$ leaf spots numerous on most remaining leaves with $\leq 90 \%$ leaf loss, $9=$ few remaining leaves covered with spots with $\leq 95 \%$ leaf loss, and $10=$ plants $100 \%$ defoliated. Significance of treatment effects was tested by analysis of variance and Fisher's protected least significant difference (LSD) test $(P=0.05)$.

While daily temperatures were near normal for much of the 2005 growing season, unseasonably dry weather occurred from early April to late May and again in October. Due to several tropical weather systems and almost daily showers, rainfall totals for June, July, and August were unusually high. While temperatures were above average in June, July, and August 2006, rainfall totals for April, May, and June were well below the historical average but average to above average for August, September, and October. 
Results and Discussion: As of 2 July 2005, no symptoms of Cercospora leaf spot were observed (data not shown). By 24 August, noticeable leaf spotting and a low level of defoliation were seen on the SunSpray Ultra Fine Oil-treated and untreated control trees (Table 1). In addition, light leaf spotting in the lower leaf canopy was noted on this date on the crapemyrtle treated with the remaining eight fungicides. By 25 October, significant differences in the level of disease control between the fungicide programs were recorded. The least leaf spotting and little if any premature leaf loss was observed on the Heritage 50W-and Bayer Advanced Disease Control-treated crapemyrtle. Ferti-loam Liquid Systemic Fungicide, Cleary's 3336 4.5F, and Immunox also slowed the spread of Cercospora leaf spot. When compared with the untreated control, some control of Cercospora leaf spot was also obtained with SunSpray Ultra Fine Oil and SA Systemic Fungicide.

Disease development accelerated between 24 July 2006 when a low level of leaf spotting was seen and 31 August. By 27 September, the least leaf spotting was noted on the Cleary's 3336 4.5F, Heritage 50W, and Bayer Advanced Disease Control-treated crapemyrtle (Table 1). Surprisingly, the SunSpray Ultra Fine Oiltreated crapemyrtle had leaf spot ratings that were identical to those recorded for Heritage 50W and Bayer Advanced Disease Control. Disease incidence on the untreated control, Neem Concentrate, and SA Systemic Fungicide-treated crapemyrtle was similar. No phytotoxicity was observed with any fungicide treatments.

Over the two-year study period, the retail fungicides Bayer Advanced Disease Control for Roses, Flowers, and Shrubs, Spectracide Immunox, and ferti-loam Liquid Systemic Fungicide as well as the commercial fungicides Heritage 50W and Cleary's 3336 4.5F slowed the spread of Cercospora leaf spot and minimized disease-related defoliation. Hagan and Akridge (2) saw similar results with Heritage 50W on a shrub rose for the control of Cercospora leaf spot. As a result, trees protected from Cercospora leaf spot with the above fungicides had much fuller leaf canopy and better fall color than the untreated controls. A formulation of Cleary's 3336 is sold in garden centers and other retail outlets by the trade name ferti-loam Halt 50W. In one of two years, SunSpray Ultra Fine Oil proved as effective in controlling Cercospora leaf spot as all of the above fungicides. Previously, this fungicide failed to control Cercospora leaf spot on flowering dogwood compared with Cleary's 3336 and Liquid Systemic Fungicide (3). Neem Concentrate, SA Systemic Fungicide, and ferti-loam Blackspot and Powdery Mildew Control were the least effective of the fungicides tested for the control of Cercospora leaf spot on crapemyrtle. The lack of efficacy shown by Neem Concentrate here was similar to the results obtained with this product against Cercospora leaf spot on flowering dogwood (3). 


\section{Literature Cited:}

1. Dirr, M. A. 1998. Manual of Woody Landscape Plants. $5^{\text {th }}$ edition. Stipes Publishing Co. Champaign, IL.

2. Hagan A. K. and J. R. Akridge. 2005. Fungicides control Cercospora leaf spot on Fuchsia Meidland rose. Alabama Agri. Exp. Stn. Cir. 329.

3. Hagan A. K. and J. R. Akridge. 2007. Comparison of synthetic and organic fungicides for the control of spot anthracnose, powdery mildew, and Cercospora leaf spot on flowering dogwood in Alabama. Alabama Agri. Exp. Stn. Bull. 668.

4. Hagan, A. K., G. J. Keever, C. H. Gilliam, J. D. Williams, and G. Creech. 2002. Resistance of selected crapemyrtle cultivars to powdery mildew and Cercospora leaf spot. Alabama Agri. Exp. Stn. Bull. 644.

5. Williams-Woodward, J. L. and J. W. Buck. 2002. Fungicide efficacy and spore dispersal of Cercosporidum needle blight on Leyland cypress. Proc. SNA Res. Conf. 47:245-249.

Table 1. Comparison of fungicides for the control of Cercospora leaf spot on Wonderful White crapemyrtle.

\begin{tabular}{|c|c|c|c|c|}
\hline \multirow[b]{3}{*}{ Treatment and rate $/ 100 \mathrm{gal}$} & \multicolumn{4}{|c|}{ Cercospora leaf spot rating* } \\
\hline & \multicolumn{2}{|c|}{2005} & \multicolumn{2}{|c|}{2006} \\
\hline & 24 Aug & 25 Oct & 31 Aug & 27 Sep \\
\hline $33364.5 \mathrm{~F} 20 \mathrm{fl} \mathrm{oz}$ & $2.6 \mathrm{bcd}^{* *}$ & $4.5 \mathrm{~cd}$ & $2.4 \mathrm{bc}$ & $3.3 \mathrm{~d}$ \\
\hline Liquid Systemic Fungicide 0.4 gal & $2.5 \mathrm{bcd}$ & $4.5 \mathrm{~cd}$ & $2.5 \mathrm{bc}$ & $3.3 \mathrm{~d}$ \\
\hline Bayer Advanced Disease Control 0.6 gal & $2.1 \mathrm{~cd}$ & $3.0 \mathrm{~d}$ & $2.1 \mathrm{c}$ & $3.0 \mathrm{~d}$ \\
\hline SA Systemic Fungicide $1.5 \mathrm{gal}$ & $1.5 \mathrm{~d}$ & $5.0 \mathrm{bc}$ & $2.8 \mathrm{abc}$ & $4.8 \mathrm{abc}$ \\
\hline Neem Concentrate $0.8 \mathrm{gal}$ & $2.4 \mathrm{bcd}$ & $5.5 \mathrm{abc}$ & $3.3 \mathrm{ab}$ & $5.0 \mathrm{ab}$ \\
\hline Immunox $100 \mathrm{fl} \mathrm{oz}$ & $2.4 \mathrm{bcd}$ & $4.0 \mathrm{~cd}$ & $2.3 \mathrm{c}$ & $4.0 \mathrm{bcd}$ \\
\hline $\begin{array}{l}\text { Blackspot and Powdery Mildew Control } \\
40 \mathrm{fl} \mathrm{oz}\end{array}$ & $3.0 \mathrm{bc}$ & $6.3 \mathrm{ab}$ & $2.1 \mathrm{c}$ & $3.8 \mathrm{~cd}$ \\
\hline Heritage 50W 4 oz & $2.8 \mathrm{bcd}$ & $3.0 \mathrm{~d}$ & $2.3 \mathrm{c}$ & $3.0 \mathrm{~d}$ \\
\hline SunSpray Ultra Fine Oil 0.8 gal & $4.5 \mathrm{a}$ & $5.0 \mathrm{bc}$ & $1.9 \mathrm{c}$ & $3.3 \mathrm{~d}$ \\
\hline Unsprayed Control & $3.6 a b$ & $7.0 \mathrm{a}$ & $3.6 \mathrm{a}$ & $5.8 \mathrm{a}$ \\
\hline
\end{tabular}

${ }^{*}$ Cercospora leaf spot-related incidence and premature defoliation was visually rated using the 1 to 10 modified peanut leaf spot rating scale.

${ }^{* *}$ Means in the same column that are followed by the same letter are not significantly different according to Fisher's protected least significant difference test $(\mathrm{P}=0.05)$. 


\title{
Evaluation of Hydrangea macrophylla Cultivars for Resistance to Powdery Mildew
}

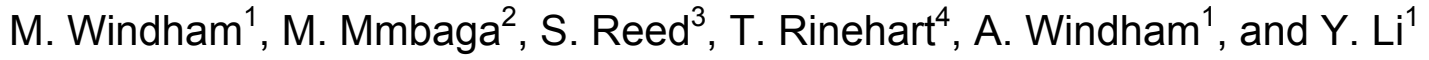 \\ ${ }^{1}$ University of Tennessee, Knoxville, TN 37996-4560 \\ ${ }^{2}$ Tennessee State University, Nursery Research Center \\ McMinnville, TN 37110 \\ ${ }^{3}$ US National Arboretum, USDA-ARS, McMinnville, TN 37110 \\ ${ }^{4}$ Thad Cochran Southern Horticultural Laboratory, Poplarville, MS 39470
}

Index words: hydrangea, powdery mildew, Erysiphe polygoni

Significance to Industry: Variation for resistance to powdery mildew was observed among 77 cultivars of $H$. macrophylla. Ten $H$. macrophylla ssp. macrophylla ('Blauer Prinz', 'Blaumeise', 'Endless Summer', 'Fasan', 'Fuji Waterfall', 'Lemon Wave', 'Taube', 'Todi', 'Tricolor' and 'Veitchii') and nine $H$. macrophylla ssp. serrata ('Amagi Amacha', 'Blue Billow', 'Diaden', 'Hokaido', 'Komachi', 'Miyama Yae Murasaki', 'Omacha', 'Pretty Maiden' and 'Shirofuji') cultivars exhibited the most resistance to powdery mildew. Information from this study will assist landscapers in choosing resistant cultivars with varying in horticultural characters and help plant breeders select parents for developing improved cultivars with resistance to powdery mildew.

Nature of Work: Hydrangea macrophylla, commonly know as bigleaf, garden, florist or French hydrangea, is a popular summer-flowering ornamental shrub. While initially considered hardy only to U.S.D.A. cold hardiness zone 6 , the introduction of remontant (reflowering) cultivars, such as Endless Summer ${ }^{\mathrm{TM}}$ and 'Penny Mac', has expanded the area of the country where the species will flower reliably (1). In addition, new hydrangea cultivars with interesting flower colors and inflorescence forms from Europe and Japan have further stimulated the interest of landscapers and gardeners in this species.

Powdery mildew, Erysiphe polygoni DC, can become a significant problem on hydrangeas in late summer to fall. Dirr (1) listed $H$. arborescens, $H$. macrophylla, $H$. paniculata, and $H$. serrata as being susceptible to powdery mildew and concluded that $H$. macrophylla was the most susceptible species. In 2001, Dirr evaluated $27 \mathrm{H}$. macrophylla ssp. macrophylla and $8 \mathrm{H}$. macrophylla ssp. serrata cultivars for powdery mildew resistance. 'Veitchii' was the only cultivar of $H$. macrophylla that did not have signs of powdery mildew. Experimental design details and a statistical analysis were not presented for that study.

Rooted cuttings of 77 hydrangea cultivars (Table 1) were obtained from Bell Family Nursery, Aurora, OR 97002 . This included 59 H. macrophylla ssp. 
macrophylla and $15 \mathrm{H}$. macrophylla ssp. serrata cultivars. The remaining three cultivars in this study appear, based on molecular data, to be hybrids between these two subspecies (2). The plants were potted in $11.4 \mathrm{~L}$ ( 3 gallon) containers in shredded pine bark amended with $7.6 \mathrm{~kg} / \mathrm{m}^{3}\left(12.8 \mathrm{lb} / \mathrm{yd}^{3}\right)$ 19-5-9 Osmocote Pro fertilizer (Scotts-Sierra Horticultural Products Co., Maryville, $\mathrm{OH}), 0.9 \mathrm{~kg} / \mathrm{m}^{3}(1.5$ $\mathrm{lb} / \mathrm{yd}^{3}$ ) Micromax (Scotts-Sierra Horticultural Products Co.), $0.6 \mathrm{~kg} / \mathrm{m}^{3}\left(1.0 \mathrm{lb} / \mathrm{yd}^{3}\right)$ iron sulfate and $0.6 \mathrm{~kg} / \mathrm{m}^{3}\left(1.0 \mathrm{lb} / \mathrm{yd}^{3}\right)$ lime. Plants were placed under $60 \%$ shade and arranged in a completely random design with four replications. Plants were micro-irrigated with spray stakes.

Resistance to powdery mildew was evaluated on September 1 and 21, 2006, using the following scale: $0=$ no signs of powdery mildew; $1=<2 \%$ of foliage has signs of powdery mildew; $2=<10 \%$ of foliage has signs of powdery mildew; $3=<25 \%$ of foliage has signs of powdery mildew; $4=<50 \%$ of foliage has signs of powdery mildew; $5=>50 \%$, but $<100 \%$ of foliage has signs of powdery mildew; $6=100 \%$ of foliage had signs of powdery mildew. Data were analyzed using the PROC GLM Model of SAS and means were separated using the test for least significant difference (LSD).

Results and Discussion: Hydrangea macrophylla cultivars were variable for resistance to powdery mildew (Table 1). On September 1, 42 cultivars were rated in the most resistant grouping. The epidemic of powdery mildew continued to become more severe over the next 3 weeks and when data were collected on September 21, only 19 cultivars were in the most resistant grouping. During the second rating, the $H$. macrophylla ssp. serrata cultivars 'Amagi Amacha', 'Blue Billow', 'Komachi' and 'Pretty Maiden' had no signs of powdery mildew in any replication. Although we observed powdery mildew on the cultivar 'Veitchii', which conflicts with observations made by Dirr (1), the amount of mildew was low and the cultivar was partitioned in the most resistant grouping $(p=0.05)$. A high level of resistance was also found in H. macrophylla ssp. macrophylla 'Blauer Prinz', 'Blaumeise', 'Endless Summer', 'Fasan', 'Fuji Waterfall', 'Lemon Wave', 'Taube', 'Todi' and 'Tricolor' and H. macrophylla ssp. serrata 'Diaden', 'Hokaido', 'Miyama Yae Murasaki', 'Omacha' and 'Shirofuji'.

Nineteen cultivars with resistance to powdery mildew provide landscapers choices in resistant cultivars varying in horticultural characters. This pool of resistant cultivars may also help plant breeders develop additional remontant hydrangea cultivars with resistance to powdery mildew.

\section{Literature Cited:}

1. Dirr, M. A. 2004. Hydrangeas for American Gardens. Timber Press. Portland, OR. 97204. 236pp.

2. Reed, S.M. and T.A. Rinehart. 2007. Simple sequence repeat marker analysis of genetic relationships within Hydrangea macrophylla. J. Amer. Soc. Hort. Sci. 132:341-351. 


\section{Acknowledgements}

Mention of trade names or commercial products in this article is solely for the purpose of providing specific information and does not imply recommendation or endorsement by the U.S. Department of Agriculture. 
Table 1. Comparison of disease index of powdery mildew among Hydrangea macrophylla cultivars in McMinnville, Tenn. during 2006.

\begin{tabular}{|c|c|c|c|c|c|c|c|c|c|}
\hline \multirow[t]{2}{*}{ Cultivar } & \multicolumn{9}{|c|}{ Cultivar } \\
\hline & \multicolumn{2}{|c|}{ Sep 1} & \multicolumn{2}{|c|}{ Sep 21} & & \multicolumn{2}{|c|}{ Sep 1} & \multicolumn{2}{|c|}{ Sep 21} \\
\hline Sister Therese & 4.7 & & 4.7 & & Forever Pink & 1.7 & cdefgh & 2.7 & defghi \\
\hline Lilacina & 4.7 & & 5.3 & & Tovelit & 1.7 & cdefgh & 3.7 & abcdef \\
\hline Libelle & 4.0 & & 5.0 & & Souv. Pres. Doumer & 1.7 & cdefgh & 3.0 & cdefgh \\
\hline Preziosa & 4.0 & & 5.3 & & Otaska & 1.7 & cdefgh & 3.0 & cdefgh \\
\hline Grayswood & 4.0 & & 3.3 & bcdefg & Tricolor & 1.3 & defgh & 0.3 & $\mathrm{kl}$ \\
\hline Goliath & 3.3 & $a b c$ & 3.7 & bcdef & Ami Pasquier & 1.3 & defgh & 2.7 & defghi \\
\hline Tokyo Delight & 3.3 & $\mathrm{abc}$ & 4.7 & bc & Blauer Prinz & 1.3 & defgh & 1.0 & ijkl \\
\hline Matilda Gutges & 3.3 & $a b c$ & 3.3 & bcdefg & Blue Bird & 1.3 & defgh & 4.0 & abcde \\
\hline Blue Wave & 3.3 & $a b c$ & 4.7 & bc & Altona & 1.3 & defgh & 2.7 & defghi \\
\hline Enziandom & 3.0 & abcd & 5.3 & & Amagi Amacha & 1.0 & efgh & 0.0 & I \\
\hline Holstein & 3.0 & abcd & 3.7 & bcdef & Kluis Superba & 1.0 & efgh & 2.3 & efghij \\
\hline Hamburg & 2.7 & bcde & 4.3 & bcd & Komachi & 1.0 & efgh & 0.0 & I \\
\hline Nikko Blue & 2.7 & bcde & 3.3 & bcdefg & Oregon Pride & 1.0 & efgh & 3.7 & abcdef \\
\hline Domotoi & 2.7 & bcde & 5.0 & & Glowing Embers & 1.0 & efgh & 2.5 & efghi \\
\hline Bodensee & 2.7 & bcde & 4.3 & bcd & Mme. Faustin Travouillon & 1.0 & efgh & 2.0 & fghijk \\
\hline Mousmee & 2.7 & bcde & 4.7 & bc & Nigra & 1.0 & efgh & 4.0 & abcde \\
\hline Nightingale & 2.7 & bcde & 3.3 & bcdefg & Taube & 1.0 & efgh & 1.7 & ghijkl \\
\hline Penny Mac & 2.7 & bcde & 3.0 & cdefgh & Mme. Emile Mouillere & 1.0 & efgh & 2.7 & defghi \\
\hline Geoffrey Chadbund & 2.7 & bcde & 3.3 & bcdefg & Ayesha & 1.0 & efgh & 2.3 & efghij \\
\hline Gerta Steiniger & 2.5 & bcdef & 4.0 & bcde & Veitchii & 0.7 & fgh & 0.7 & jkl \\
\hline Miss Belgium & 2.3 & bcdef & 4.7 & & Fuji Waterfall & 0.7 & fgh & 1.7 & ghijkl \\
\hline Trophy & 2.3 & bcdef & 3.3 & bcdefg & Todi & 0.7 & fgh & 1.0 & $\mathrm{ijkl}$ \\
\hline Dooley & 2.3 & bcdef & 4.7 & bc & Coerulea & 0.7 & fgh & 3.3 & bcdefg \\
\hline Miss Hepburn & 2.3 & bcdef & 4.3 & bcd & La France & 0.7 & fgh & 3.3 & bcdefg \\
\hline Frillibet & 2.3 & bcdef & 3.7 & bcdef & Endless Summer & 0.3 & fgh & 1.3 & hijkl \\
\hline Beaute Vendomoise & 2.0 & cdefg & 4.0 & bcde & All Summer Beauty & 0.3 & gh & 3.3 & bcdefg \\
\hline Seafoam & 2.0 & cdefg & 2.3 & efghij & Konigstein & 0.3 & gh & 2.0 & fghijk \\
\hline $\begin{array}{l}\text { Gen. Vicom } \\
\text { Vibraye }\end{array}$ & 2.0 & cdefg & 2.3 & efghij & Diaden & 0.3 & gh & 0.7 & $\mathrm{jkl}$ \\
\hline Merritt's Supreme & 2.0 & cdefg & 2.3 & efghij & Lemon Wave & 0.3 & gh & 0.3 & $\mathrm{kl}$ \\
\hline Blaumeise & 2.0 & cdefg & 1.7 & ghijkl & Fasan & 0.0 & $\mathrm{~h}$ & 0.3 & $\mathrm{kl}$ \\
\hline Gertrude Glahn & 2.0 & cdefg & 3.7 & bcdef & Miyama Yae Murasaki & 0.0 & $\mathrm{~h}$ & 0.3 & $\mathrm{kl}$ \\
\hline Marechal Foch & 2.0 & cdefg & 3.7 & bcdef & Pretty Maiden & 0.0 & $\mathrm{~h}$ & 0.0 & I \\
\hline Intermedia & 2.0 & cdefg & 4.0 & bcde & Shirofuji & 0.0 & $\mathrm{~h}$ & 0.3 & $\mathrm{kl}$ \\
\hline Parzival & 2.0 & cdefg & 4.3 & bcd & Blue Billow & 0.0 & $\mathrm{~h}$ & 0.0 & I \\
\hline Bouquet Rose & 1.7 & cdefgh & 3.3 & bcdefg & Beni Gaku & 0.0 & $\mathrm{~h}$ & 2.7 & defghi \\
\hline Charme & 1.7 & cdefgh & 2.3 & efghij & Hokaido & 0.0 & $\mathrm{~h}$ & 0.7 & jkl \\
\hline Miranda & 1.7 & cdefgh & 2.7 & defghi & Omacha & 0.0 & $\mathrm{~h}$ & 0.3 & $\mathrm{kl}$ \\
\hline Blue Deckle & 1.7 & cdefgh & 2.0 & fghijk & & & & & \\
\hline
\end{tabular}

${ }^{z}$ For each date, means followed by the same letter in a column for each variable are not significantly different from each other at the $P=0.05$ level using the least significant difference (LSD). 


\title{
Controlling Foliar Disease with ZeroTol
}

\author{
W. E. Copes \\ USDA/ARS Southern Horticultural Laboratory, Poplarville, MS 39470 \\ http://www.ars.usda.gov/msa/poplarville
}

Index Words: biocide, daylily rust, disinfectant, hydrogen peroxide, sterilant

Significance to Industry: My results support other published trials that weekly applications of label rates of ZeroTol on plants are not likely to control disease. However, multiple applications of ZeroTol per week can control foliar disease comparable to a fungicide. Results indicate that disease levels (pressure) will influence the number of applications per week required to achieve desirable control.

Nature of Work: ZeroTol is a disinfestant labeled for application on ornamental plants. In many chemical trials published in Fungicide and Nematicide Reports, label rates of ZeroTol at weekly applications were not effective at controlling various foliar diseases on ornamental plants (Hausbeck et al. 2002, Sconyers and Hausbeck 2005, Wegulo and Vilchez 2006). With this in mind, I performed a series of laboratory and field experiments using daylily rust, caused by Puccinia hemercallidis, to evaluate application schedules of ZeroTol.

Laboratory experiments were done to obtain a dose response. Daylily leaves with rust pustules were cut into $3 \mathrm{~cm}$ lengths of a leaf, and a series of rates from 0 to $12 \%$ active ingredient of hydrogen dioxide were applied to leaf sections. Leaves were rubbed across the surface of potato dextrose agar to dislodge uredinospores. The following day, percent germination was counted. The experiment was done three times.

A field experiment was done to test the label rate, and two excessively high rates, as determined in the laboratory experiment. Healthy plants were paired with plants that had sporulating rust pustules. Both plants were sprayed weekly with rates of ZeroTol. Check treatments included: an untreated treatment (water applied once a week) and a standard control treatment [an application of Heritage (oxystrobin) followed in 2 weeks by Spectrum (chlorothalonil and thiophanate methyl)]. The experiment was performed twice.

A greenhouse experiment was done to test rates labeled for application on plants ( 0.75 and $1 \%$ ZeroTol) and on inert surfaces ( $1.25 \%$ ZeroTol) that were applied 2,3 , and 5 times per week to plants. Based on how rates are listed on the label, equivalent rates are a 1:100 ZeroTol : water dilution (curative rate, $=11 / 4 \mathrm{oz}$ ZeroTol per gal of water, $=1 \%$ ZeroTol) and a $1: 133$ dilution (= 1 oz per gal, = $0.75 \%$ ZeroTol). Treatments were randomized and applied on healthy plants. 
Plants with active rust sporulation were placed between healthy plants and were not treated. Check treatments included an untreated treatment (water applied once a week) and a standard control treatment (an application of Heritage (oxystrobin) followed in 2 weeks by Spectrum (chlorothalonil and thiophanate methyl)]. The experiment was performed twice.

\section{Results and Discussion:}

In the laboratory experiment, higher than label rates (12\% hydrogen dioxide, DO NOT APPLY THIS RATE) were required to achieve a $100 \%$ mortality of rust spores. In a field trial experiment, the same extremely high rate was required with weekly applications of ZeroTol to achieve daylily rust disease control equal to the fungicide treatment. As expected, the high rate of ZeroTol caused severe plant damage. A weekly application of the curative label rate was not effective.

My results support findings reported in other published trials that weekly applications of label rates of ZeroTol are not likely to be effective. This can be explained because all disinfestants, including ZeroTol, do not provide the residual protection typically provided by standard fungicides. Fungicides persist either on plant surfaces or systemically in plant tissue to provide a residual protection against infection for 7 to 21 days, depending on the fungicide and environmental conditions. Disinfestants kill pathogen propagules, such as fungal spores, that are present on plant surfaces during application, but do not provide any residual protection. Therefore, newly arriving aerially- or water-dispersed spores can cause infection within days after applying a disinfestant.

HOWEVER, NOT ALL HOPE IS LOST. ZeroTol can be effective. In the greenhouse study, multiple applications per week of ZeroTol did not damage daylily plants and provided rust control equal to fungicides when rust incidence was relatively low, but provided poor control when rust incidence was high. Even when disease incidence was high as a result of higher disease pressure, ZeroTol still imparted some disease control as evidenced by lower disease severity levels compared to the water treatment.

\section{MY CONCLUSIONS AND SUGGESTIONS:}

1. Multiple applications of ZeroTol per week can control foliar disease comparable to a fungicide. However, disease levels will influence the number of applications per week required to achieve desirable control. Additional research is needed with several foliar diseases under several disease pressure levels to properly define rates and number of applications per week (daily to every-second or third day).

2. Frequent applications could be applied through the irrigation system to reduce application costs. Short duration watering (in seconds) is all that is needed to wet leaves (treat plants).

3. If disease levels are noticeably increasing, then apply an appropriate fungicide. 
WARNINGS: A.) The lowest rate listed on the product label (1:300 dilution, preventative rate) was not tested in the above trials. The ZeroTol label does not list prolonged usage of the curative rate (1:100 dilution) which was used in this trial. Research is being done to test if different pathogens respond differently. B.) Ornamental plant genera/species/cultivars vary in sensitivity to ZeroTol, therefore you should test safety of the product at the rate and application interval that will be used on a sample set of plants before applying it at a production level (Copes et al. 2003).

The above results are one part of my research program. Currently, I am working to improve our understanding of how to maximize the benefit of disinfestants when treating production surfaces and to reduce the occurrence of Rhizoctonia web blight of azalea in nurseries through the use of integrated disease control methods. It is likely that the methods devised to control Rhizoctonia will be useful in controlling other pathogens as well and be applicable in greenhouse production systems.

\section{Literature Cited:}

1. Copes, W. E. 2004. Dose curves of disinfestants applied to plant production surfaces to control Botyrtis cinerea. Plant Disease 88:509-515.

2. Copes, W. E., Chastaganer, G. A., and Hummel, R. L. 2003. Toxicity responses of herbaceous and woody ornamental crops to chlorine and hydrogen dioxides. Online. Plant Health Progress dol:10.1094/PHP-20030311-01-RS. (http://www.plantmanagementnetwork.org/php/)

3. Hausbeck, M. K., Cortright, B. D., and Linderman, S. D. 2002. Evaluation of registered and unregistered fungicides in managing Botrytis blight of geranium, 2000. Fungicide and Nematicide Tests 58:OT020.

4. Sconyers, L. E. and Hausbeck, M. K. 2005. Evaluation of biological and biorational products in managing powdery mildew of African daisy, 2004. Fungicide and Nematicide Tests 60:OT001.

5. Wegulo, S. N., and Vilchez, M. 2006. Evaluation of fungicides for control of downy mildew of Limonium, 2005. Fungicide and Nematicide Tests 61:OT029.

\section{Disclaimer}

Mention of a trademark, proprietary product, or vendor does not constitute a guarantee or warranty of the product by the Department of Agriculture and does not imply its approval to the exclusion of other products or vendors that also may be suitable. 
SNA Research Conference Vol. 522007 